\title{
A model for quantifying construction waste in projects according to the European waste list
}

C. Llatas

Departamento de Construcciones Arquitectónicas I, Universidad de Sevilla, ETS de Arquitectura, IUACC, Avda. Reina Mercedes 2, 41012, Sevilla, Spain

Date: 12th October 2010

Tel.: +34954556591

Fax: +34 954556591

e-mail address: cllatas@us.es 


\begin{abstract}
The new EU challenge is to recover $70 \%$ by weight of C\&D waste in 2020 . Literature reveals that one major barrier is the lack of data. Therefore, this paper presents a model which allows technicians to estimate C\&D waste during the design stage in order to promote prevention and recovery. The types and quantities of $\mathrm{CW}$ are estimated and managed according to EU guidelines, by building elements and specifically for each project. The model would allow detection of the source of the waste and to adopt other alternative procedures which delete hazardous waste and reduce CW. Likewise, it develops a systematic structure of the construction process, a waste classification system and some analytical expressions which are based on factors. These factors depend on technology and represent a standard on site. It would allow to develop a database of waste anywhere. A Spanish case study is covered. Factors were obtained by studying over 20 dwellings. The source and types of packaging waste, remains, soil and hazardous waste were estimated in detail and were compared with other studies. Results reveal that the model can be implemented in projects and the chances of reducing and recovery C\&D waste could be increased, well above the EU challenge.
\end{abstract}

Keywords: Construction Waste, Construction Waste Classification, Construction Waste Quantification, European Waste List, Construction Waste Management 


\section{Introduction}

Debris from construction and demolition projects constitutes $35 \%$ of solid waste in the world (Construction Materials Recycling Association, 2005; Hendriks and Pietersen, 2000), the majority ends up in landfills, in uncontrolled sites or in other inappropriate places. This common practice causes a number of impacts on the environment, including pollution of air, surface water and underground water, risks to public health and loss of natural resources. Given the need to prevent and manage C\&D waste, several countries and their governments have developed and implemented a great number of environmental regulations, in order to obtain long-running protection of the environment so that future generations can also make use of natural resources (World Commission on Environment and Development (WCED), 1987).

The concept of sustainable development has also resulted in a gradual consolidation within the EU legislative framework, in which dwelling and construction have long been considered most likely to meet the established goals because this sector-waste-generation is disproportionately high (European Economic and Social Committee, 1997). In most of the EU member states the strongest demand for resources comes from construction projects and the single largest waste stream is from C\&D waste generated largely by intensive construction activities, accounting for $82.7 \%$ of all waste produced by economic activities (Eurostat, 2009), and $48 \%$ of total waste in EU-15 (European Environmental Agency, 2007). As the rate of construction in the EU is set to increase, one of the greatest challenges facing the recent EU Directive on waste (European Parliament, 2008) is to become a "recycling society". From now on all EU member states will have to take the necessary measures to ensure that, by 2020 , $70 \%$ by weight of non-hazardous waste from C\&D waste (with the exclusion of noncontaminated soil and rocks from excavation) are intended for reuse, recycling and material recovery operations, including filling operations using waste to replace other materials.

However, the actual management of C\&D waste in many European countries is far from this major goal in the EU. In Spain for example, it is estimated that $70 \%$ of total waste is C\&D waste (Hendriks and Pietersen, 2000). The production of C\&D waste grew in the period 2001-2006 at an average rate of $8.7 \%$ annually, over $50 \%$ was discharged uncontrollably, over $30 \%$ was sent directly to landfill or rejected from preliminary treatment, and less than $8 \%$ was recovered and 
recycled as aggregate (Spanish Government - Ministry of the Environment, 2009), still far from $70 \%$ of the EU goal.

One of the main barriers to achieve this objective is that in spite of C\&D waste having long been a worldwide priority, there is still insufficient knowledge about this waste stream. It was known that the major part of C\&D waste is generally inert (Franklin Associates, 1998), and therefore may not pose an environmental threat as great as hazardous waste or typical MSW (Wang et al., 2004). This feature has precisely meant that they have not been controlled in many regions with respect to other waste streams, which has resulted in lack of data and statistics on this waste flow. In the US, for example, a recent study indicates that the actual amount of C\&D debris generated is unknown (Cochran and Townsend, 2010). In Europe, most data available today is extracted from the study undertaken by several European consultants for the European Commission in 1999 (Symonds, 1999). And in Spain the current National Plan of Construction Waste recognises that it has not been possible to determine an exact figure for annual production of C\&D waste due to the lack of reliable statistics (Spanish Government Ministry of the Environment, 2009).

To improve the current management of $C \& D$ waste and to find out more about its composition and amounts generated for prevention and to obtain high recycling rates, it is absolutely necessary to become aware from the very origin: the construction project. C\&D waste originates within the lifecycle of buildings, during construction, modification and demolition phases (Esin and Cosgun, 2006). Several studies have identified the design stage as one of the main causes which generates a substantial amount of construction waste as a result of poor design concepts and decisions (e.g.: Osmani et al., 2007, Osmani et al., 2006, Innes, 2004; Chandrakanthi et al., 2002; Ekanayake and Ofori, 2000; Faniran and Caban, 1998; Bossink and Brouwers, 1996). Other studies have indicated the importance of including in any construction project, plans for recycling waste materials prior to the commencement of work, identifying the types of waste to be generated, the method of handling, and recycling and disposal procedures (e.g.: Batayneh et al., 2007, Jaillon et al., 2008). In view of this the Spanish government is facing this EU primary challenge within recent legislative framework in which the document of the project becomes a key-piece in the prevention and management of C\&D waste. With the entry into force of the National Decree 105/2008 (Spanish Government - 
Ministry of the Presidency, 2008), technicians have to include in construction projects a new document called Waste Management Study (WMS). Among other issues, it must contain an estimate of the amount of C\&D waste expected to be generated on site, classified and coded according to the European Waste List (EWL) in order for efficient prevention and management from the very beginning of the project.

However, there is still no awareness that C\&D waste is a potential economic resource to be taken into account during the design phase. Thus, in most cases, construction waste is simply estimated globally in projects, limiting the chances of prevention and recovery on site and therefore posing a significant barrier to achieving the EU and Spanish goals (Llatas and Huete, 2009). Literature reviewed reveals that one of the main hindrances is the lack of data, studies and poor documentation of waste generation rates and composition and particularly regarding this EU legal classification. In fact, some WMS models provided by professional associations of architects use the percentages obtained long ago in a study of the composition of debris brought to its landfills (Spanish Government - Ministry of the Environment, 2001) to estimate the quantity of C\&D waste in projects. This approach is considered unreliable because the composition and quantities of C\&D waste vary considerably from one project to another (Jaillon et al., 2008) due to the large amount and its complexity (Begum et al., 2007).

Given these shortcomings, the objective of this research is to promote the chances for reduction and recovery of construction waste through its consideration from the very origin: the construction project. Therefore the aim of this paper is to present a model for quantifying the expected amount of debris produced from construction projects following the waste divisions used by the EU and also to contribute to their objectives. The major studies of composition and quantification of C\&D waste conducted in and outside of Europe in recent years have also been collected. The main novelty of the proposed model is for C\&D waste to be provided, detailed by building elements. This would allow technicians to obtain the specific composition and quantities of C\&D waste for each project. It would also allow detection of the source of the waste on the project and evaluation of alternative construction procedures. Technicians, for example, could identify during the design process those building elements which generate a substantial amount of construction waste or/and harzadous waste, and adopt others that reduce the amount of C\&D waste generated and eliminate hazardous waste in the project. The model also develops a 
systematic structure of the construction process, a waste classification system based on the EWL and provide some analytical expressions to quantify the waste. The anaytical expressions have a universal character and are based on some factors of quantification. These factors are statistical data and represent a standard tecnology in a locality and so the model would allow the development of a database of C\&D waste anywhere. This also means that the model could detect the effects on the generation of C\&D waste on a site produced by a change in technology in the construction industry, simply requiring modification of the corresponding factors of quantification to return to the waste generation ratios.

This paper also includes a case study. This has been applied to a dwelling in Andalusia. Waste quantification factors were obtained by studying over 20 dwellings built and promoted by a local authority developer within the following research: "-CDW=+ECO-efficiency. Waste Reduction in Dwelling Design and Construction in Andalusia". The source and types and quantities of packaging waste, remains, soil and hazardous waste were estimated in a detailed way and were compared with the actual amount of waste produced and with the few data on waste generation existing in Spain and obtained from the literature reviewed. The chances of preventing and recovering waste are also analysed. Results reveal that the model can be implemented in construction projects and in the future could achieve high recycling rates, well above the European challenge.

\section{Composition and quantification studies of C\&D waste}

The purpose of this section is to collect the major studies to quantify C\&D waste carried out in the last 15 years in and outside of Europe. This seeks to show the main issues of these studies with respect to the proposed model, and to obtain data on waste generation in Spain to compare them with the results of case study.

\subsection{Non-European studies}

In the United States, the study conducted by Yost and Halstead in 1996, highligted that C\&D waste generation based on per capita multipliers, in much the same way as MSW estimates, had lead to estimation rates with more than 10 -fold variation. Consequently a 
methodology based on the financial value of building permits for a variety of types of construction projects based on a database from the U.S. Census Bureau was proposed. Gypsum wallboard waste generation for a region of the United States was estimated in order to use the results in the decision-making process by a wallboard manufacturing plant interested in the development of a regional gypsum wallboard recycling programme. The National Methodology for the U. S. Environmental Protection Agency and the Industrial Solid Waste Division (Franklin Associates, 1998) was applied with a similar approach in six sectors: dwellings, non-dwelling buildings, dwelling rehabilitations, non-dwelling rehabilitations, dwelling demolitions and non-dwelling demolitions. The statistical data on the number, value and area of each debris-generating activity was multiplied by the range of waste generated in each activity.

The report for the Florida Center for Solid and Hazardous Waste Management (Reinhart et al., 2003) was based also on financial value to calculate the amount of construction, rehabilitation and demolition activity in Florida. The values obtained for each activity were multiplied by the previously estimated quantities of each type of C\&D waste. Subsequently, another study to estimate waste generated in construction, rehabilitation and demolition of buildings in Florida was based on the same principle as the aforementioned National Methodology (Cochran et al., 2007). However, this study used data from more reliable sources and took into account new estimation ranges that allowed estimate waste generation according to the constructive technique. In this way the results were obtained as nine types of waste: wood, concrete, block, drywall, asphalt, metal, plastic, ceramic and other debris. In Thailand another study employed more generally this principle of estimation (Kofoworola and Gheewala, 2009). This study applied to the information obtained from building permits a waste generation factor equal to $21.38 \mathrm{~kg} / \mathrm{m}^{2}$ in the construction of dwellings and $18.99 \mathrm{~kg} / \mathrm{m}^{2}$ in the construction of non-dwelling buildings.

Another way to estimate C\&D waste is through material stocks and flows by dynamic model technique. The quantities of C\&D waste expected in a region are carried out by studying the dynamics of collection and flow of construction materials for construction activity and future building demand. In Taiwan, for example, a study estimated the concrete waste that would be generated in the period 1981 to 2011 according to the area of permits issued through 1999 for the construction and the demolition of buildings (Hsiao et al., 2002). In Canada, simulation 
models based on the work schedule of activities, were also used to establish the generation of waste at construction sites as 5 fractions (metals, wood, plasterboard, concrete and others) (Chandrakanthi et al., 2002).

Other methods are based on databases of construction costs. In Massachusetts for example a study was carried out in which the authors took the waste factor for each building material from the company R. S. Means. This company published costs of construction and considered losses of $100 \%$ of building materials in demolition projects and in construction projects losses of $10 \%$ of building materials. This allowed the waste of wood, tile, asphalt, carpets and plasterboard to be established (Wang et al., 2004).

\subsection{European studies}

One of the first estimates of the quantities of C\&D waste was conducted in the Netherlands by studying 184 dwellings developed in 5 different projects (Bossink and Brouwers, 1996). C\&D waste was classified and weigthed according to 9 fractions: debris piles, bricks, concrete, blocks, tiles, mortars, aggregates, packages and others. One of the main conclusions was that depending on the type of building materials supplied on site, between $1 \%$ up to $10 \%$ by mass thereof becomes waste.

In Europe studies based on dynamic model technique have also been conducted. In the Netherlands for example, the collection and flow dynamics of lead from cathode ray tubes in the European Union was studied, anticipating the needs and simulating the amounts of lead generated through the year 2031 (Elshkaki et al., 2005). In the Netherlands, this procedure was also used to determine the resource demands of a region and its corresponding waste generation and emissions (Müller, 2006). More specifically this model was applied to simulate the concrete demand in dwelling buildings and waste generated in the Netherlands until 2100. In Norway a study also obtained estimates of 10 types of waste generated in the construction, rehabilitation and demolition of buildings in Trondheim by 2020 according to the following fractions: concrete, wood, plasterboard, metal, paper, plastic, glass, insulation, asbestos, hazardous and others (Bergsdal et al., 2007).

Several methods for management and quantification based on data from previous research have also been developed in Europe such as SMARTwasteTM association of BRE in the UK. 
This software tool helps to prepare, implement and review the Site Waste Management Plan for Construction Works. It includes a quantification tool that calculates the overall volume of waste in 13 different fractions of the project.

Other tools designed for the life cycle assesment of buildings are useful in the management of construction and demolition waste (Fatta and Moll, 2003), such as the Danish Building Research Institute (SBI) designed in 1999 and that of The Environment Agency for England called Wisard (waste-integrated systems assessment for recovery and disposal) designed in 1999.

\subsection{Spanish studies}

The current National Integrated Waste Plan 2007-2015 (Spanish Government - Ministry of the Environment, 2009) indicates that it was not possible to make estimates of C\&D waste given the lack of reliable statistics. However, when the Plan was at the draft stage (Spanish Government - Ministry of the Environment, 2007) it made annual estimates as shown in Figure 1 , and opted to use the rates indicated in Table 1 which were finally not included when the Plan was approved.

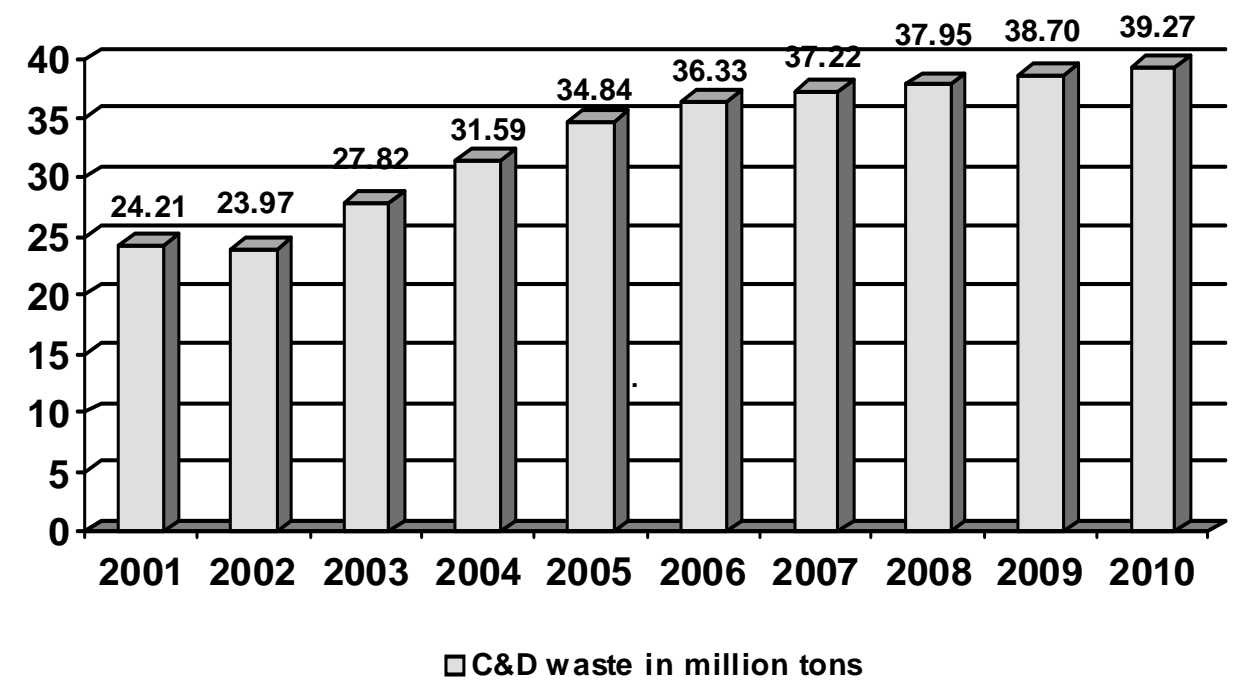

Fig. 1. C\&D waste generated in Spain since 2001. 
Table 1

C\&D waste generated in Spain (by type of construction and civil works) (t) and ratios.

\begin{tabular}{|c|c|c|c|c|c|c|}
\hline \multirow[b]{2}{*}{ Type of construction } & \multicolumn{5}{|c|}{ Years } & \multirow{2}{*}{$\begin{array}{l}\text { C\&D waste generated } \\
\text { by m }^{2} \text { of building }\end{array}$} \\
\hline & 2001 & 2002 & 2003 & 2004 & 2005 & \\
\hline new building construction & $10,270,920$ & $10,274,640$ & $11,649,720$ & $13,139,640$ & $14,149,080$ & $120.0 \mathrm{~kg} / \mathrm{m}^{2}$ constructed \\
\hline rehabilitation & 914,490 & 865,040 & $1,006,278$ & $1,010,342$ & 909,748 & $338.7 \mathrm{~kg} / \mathrm{m}^{2}$ rehabilitated \\
\hline total demolition & $4,493,420$ & $4,399,713$ & $5,444,038$ & $6,446,590$ & $7,860,098$ & 1,129.0 kg/m² demolished \\
\hline partial demolition & $1,147,064$ & $1,122,678$ & $1,231,965$ & $1,360,219$ & $1,297,898$ & $903.2 \mathrm{~kg} / \mathrm{m}^{2}$ demolished \\
\hline works without license & 841,295 & 833,104 & 966,600 & $1,097,840$ & $1,210,841$ & \\
\hline Civil works & $6,543,403$ & $6,479,649$ & $7,518,000$ & $8,538,752$ & $9,417,654$ & \\
\hline Total C\&D waste generated & $24,210,592$ & $23,974,824$ & $27,816,601$ & $31,593,383$ & $34,845,319$ & \\
\hline
\end{tabular}

Source: Draft National Integrated Waste Plan 2007-2015 (Spanish Government - Ministry of the Environment, 2007).

Three main lines of research have been identified.

a) ITeC data (ITeC, 1994), at first considered as the most reliable Spanish study (Spanish Government - Ministry of the Environment, 2007), estimated for new buildings a volume of CW, without soil, of $0.125 \mathrm{~m}^{3} / \mathrm{m}^{2}$ built, and in demolitions a volume of 0.732 to $0.874 \mathrm{~m}^{3} / \mathrm{m}^{2}$ demolished. It is identified as study (a) in Section 4.1.

b) A study of composition of C\&D waste conducted by the Autonomous Community of Madrid in its landfills (Spanish Government - Ministry of the Environment, 2001). These percentages shown in Figure 2 are used in some Spanish models to estimate the composition of C\&D waste in projects (e.g.: FIDAS, 2010). It is identified as study (b) in Section 4.1.

c) Several studies conducted at the University of Seville. One of the first studies developed a quantitative method of C\&D waste based on the Andalusian Construction Costs Database (BCCA) (Andalusian Government - Dwelling Counseling, 2010) whose task was to estimate the waste expected on site in order to estimate their withdrawal in a specific chapter within the measurements and budget document of the project (Ramirez de Arellano et al., 2002). Simultaneously another quantification method was carried out and applied to newly-constructed dwelling buildings (Llatas, 2000). The aim was to identify and quantify the types of waste expected by the execution of each building element/sitework to determine the source of the waste within the construction process. Thereafter, the first method mentioned above was 
applied in the Alcores model by studying the construction and demolition of over 100 dwellings (Solis et al., 2009). The aim was to estimate the expected volume of waste generated in new construction, rehabilitation or demolition projects for the levying of the tax imposed by the municipalities. This study is identified as study (c) in Section 4.1.

Currently, some software tools have also been developed. An example of these is the BEDEC database (BEDEC, 2010). However, the main drawback of these tools is that they do not usually provide quantification methodology, so that C\&D waste is estimated based on certain technology, therefore it is not viable for other sites where buildings are built using different technology (Llatas et al., 2010).

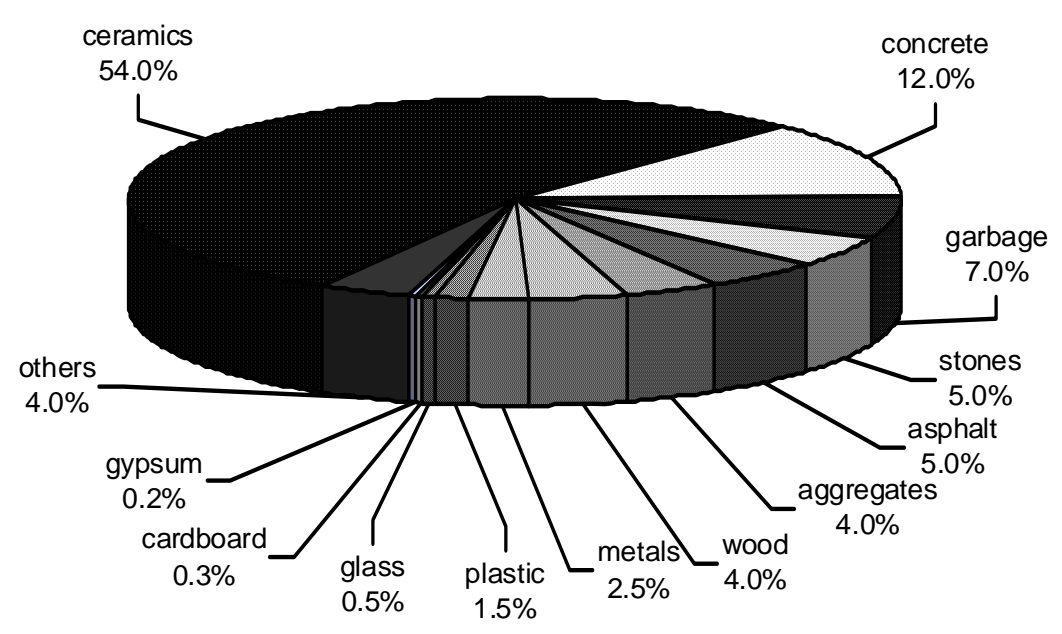

Fig. 2. Composition of C\&D waste generated in Spain.

Source: National C\&D Waste Plan 2001-2006 (Spanish Government - Ministry of the Environment, 2001).

\section{Methodology}

The steps to obtain the estimates of the quantities of C\&D waste by building elements and classified according to the EWL are explained below. 


\subsection{Premises}

Regarding C\&D waste there are two groups according to their general origin: demolition and construction waste. Demolition waste (DW) is originated as a result of the dismantling at demolition works, or when restoring and repairing buildings and facilities. $100 \%$ of the building demolished is waste (Wang et al., 2004) and it is estimated at 1,129.0 $\mathrm{kg}$ per $\mathrm{m}^{2}$ demolished as shown in Table 1 (Spanish Government - Ministry of the Environment, 2007). Construction waste $(\mathrm{CW})$ is generated as a consequence of the works executed at buildings from the foundations and up, being estimated at $120.0 \mathrm{~kg} / \mathrm{m}^{2}$ built as shown in Table 1 (Spanish Government - Ministry of the Environment, 2007). In Spain, most C\&D waste is CW generated by new building construction (Table 1). This is mixed waste of a heterogeneous nature consisting mainly of a mixture of packagings and remains. For now, this mixed waste is not usually separated into work and is removed to landfill as shown in Figure 3.

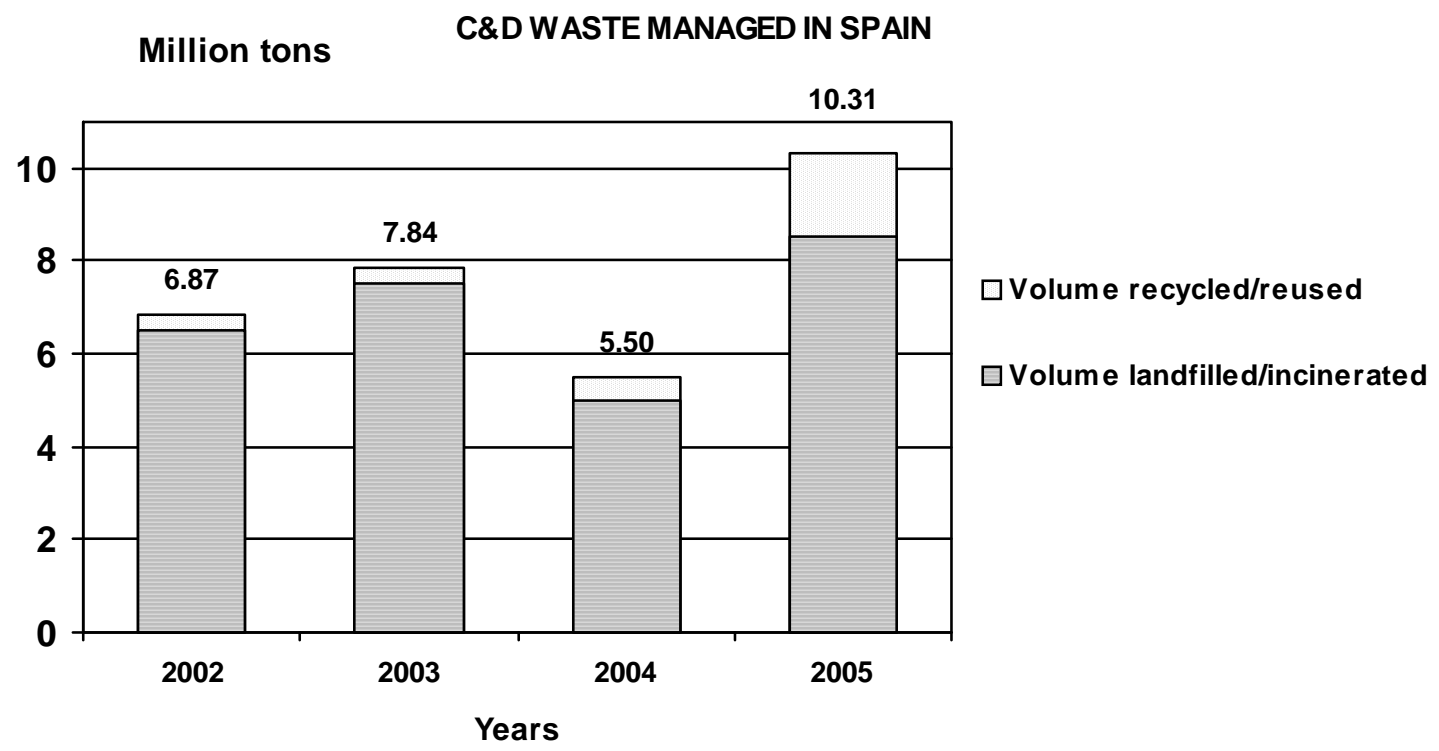

Fig. 3. C\&D waste managed in Spain (2002-2005) at treatment plants.

Source: Draft National Integrated Waste Plan 2007-2015 (Spanish Government - Ministry of the Environment, 2007).

Volume is a valuable datum because from it, the number and size of containers needed for removal can be estimated. Moreover, the cost of its disposal in this case is often applied to volume, not mass. For these reasons, the model focuses on new buildings and initially 
estimates the volume of waste. However, mass is also a valuable datum since it does not depend on the compactness of the waste. In the future, this matter should be resolved in two ways. To consider getting the average density of each type of waste, once it has been separated on site and to apply it to volumes obtained with the proposed model. Alternatively, with the reformulation and redefinition of the factors. For example, in the case of packaging waste factor, the data requested from the supplier of the product would be the mass of packaging per amount of material supplied and the application of the increased volumen factor would not need to be applied. In any case, for the purpose of this paper, the volume is also valuable information because the other studies that serve as a comparison also provide their data in volume.

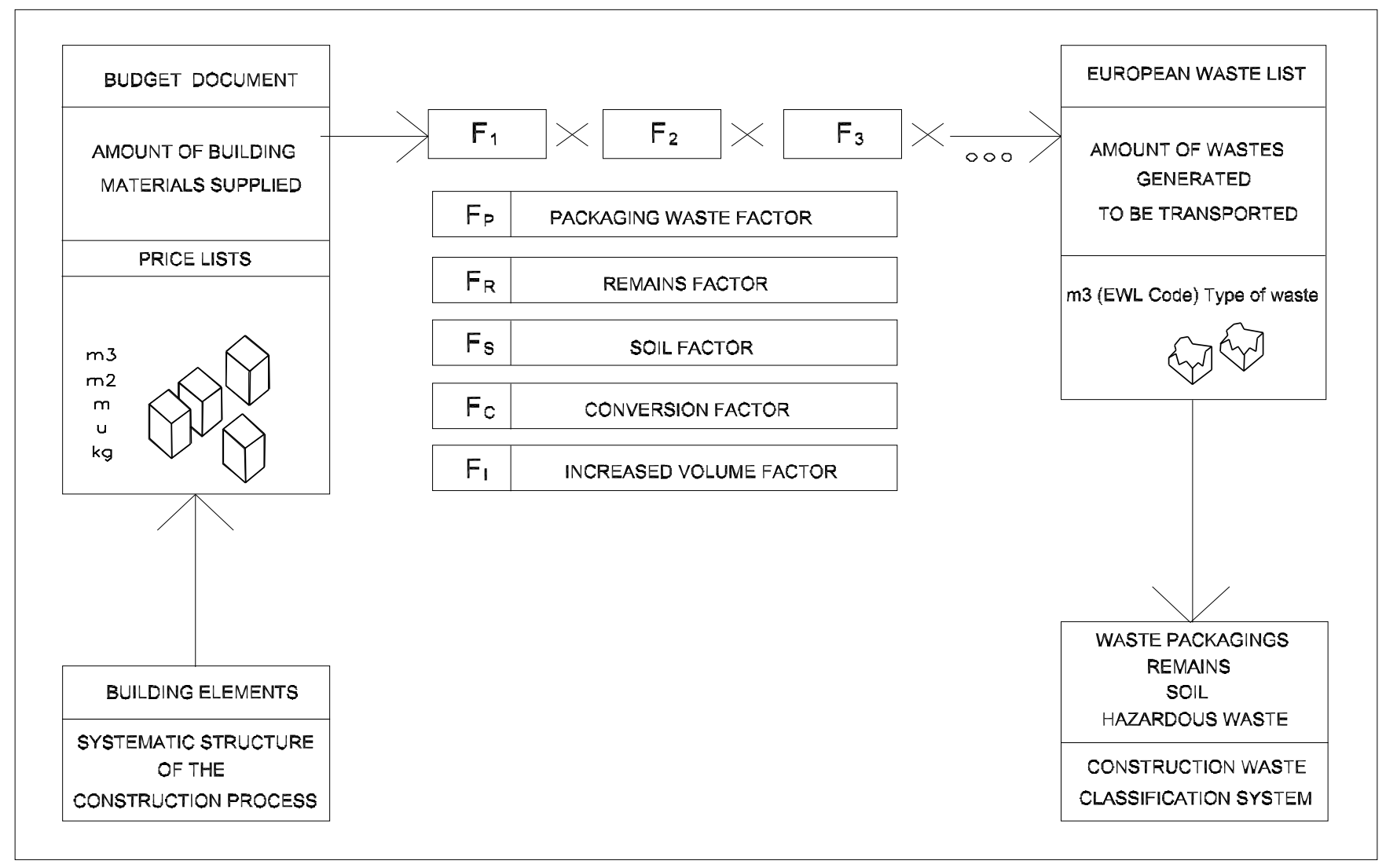

Fig. 4. Basic tools of the model.

Figure 4 is intended to illustrate how the model works. This considers the construction project as the main source of waste because in this the technician designs, locates, describes, quantifies and specifies the different building elements that are required to construct a building. As a consequence of these decisions, the execution of the works and future demolition of the 
building will certainly involve the production of waste materials. That is, the types and quantities of waste generated in a work are the result of the changes experienced by the materials supplied to it and their packaging once these are introduced into the construction process. Broadly, the model estimates the types and volume of building materials and their packagings supplied to the work. Of this volume, one part is waste. In the case of building materials this part is estimated from their percentage of losses which depends on the type of building material. In the case of packagings $100 \%$ of this volume is waste to be removed from the site. Finally greater volume is considered due to disorder or breakage.

The advantage of the model is that the estimates of the types of waste are obtained in a specific form for each project. This means that if in a project, a type of waste has been estimated by applying this model, but finally in the work, this type of waste is not generated, it is probably because this building material was not supplied to the site probably due to a project error or a last minute change. It is therefore important that the project be developed with technical quality criteria to obtain estimates of waste as close to reality as possible. This model develops three basic tools: the first tool is a systematic structure of the construction process in order to identify in the project the building/sitework elements and their materials and components. The second implementation is a waste classification system in order to obtain the list of waste coded according to the EWL. And finally it provides some analytical expressions that estimate the amount of packaging waste, remains and soil.

\subsection{Proposal of a systematic structure of the construction process}

The first step of the methodology is to identify the building elements of the project and their construction processes. This is a reason to believe that by means of identifying these processes within the execution of each building/sitework element, as the origin of the waste, the types and quantities of the generated CW may be determined. During the early stages of the work, waste is generated mainly by the execution of the enclosure of the work, cleaning and clearing of land, implementation of the access and infrastructure and the construction of premises for storage and office work. During the subsequent stage of reception of materials, waste is often generated by product damage during transport, for wrong purchases due to lack of time or lack of 
provisions in the project and supply of products of inadequate quality. During the storage stage of building materials it is important to have proper organisation and the conditions for protection of materials against atmospheric agents must be optimal. In the execution phase of the work the main causes and origin of waste are soil from excavation, remains of building materials and components because of shortages, breakages, losses, etc., and the remains of packaging; remains of auxiliary elements due to redesign, testing, temporary works, formwork, etc...; remains from handling due to lack of modulation; demolition and reconstruction due to faulty execution.

These construction processes can be known prior to the commencement of the work although they can also be modified during the execution as a result of last minute changes due to clients' requirements and 'design changes' being a major cause of waste generation (Poon et al., 2004; Osmani et al., 2006). In these cases the model should also be applied to the new building/sitework elements.

Therefore, a systematic structure of the construction process has been developed according to a Standard Classification for Building Elements and Related Sitework as have other databases, Uniformat II (National Institut of Standards and Technology, Canada, 1999) or BCCA (Andalusian Government - Dwelling Counseling, 2010). Building/sitework elements are defined as the major components/activities that are common to most buildings and that perform a given function, e.g.: footings, catchbasins, beams, pilars, collectors, etc... System building/sitework elements are defined as a group of building/sitework elements that are interrelated and coordinated among themselves, e.g.: site clearing, site earth-work, foundation, structure, masonry, roofing up to painting. Most of the terms employed are defined according to ISO (ISO 6707-1, 2004).

\subsection{Proposal of a waste classification system}

A waste classification system according to EWL has been worked out. The EWL is an integrated list of waste produced by the European Communities Committee (Commission Decision 2000/532/EC and Commission Decision 2001/118/EC) and forms an integrated basis for the classification of waste in the EU. The objective is to be a reference nomenclature providing common terminology throughout the Community with the purpose of improving the 
efficiency of waste management activities. The types of waste are divided into 20 chapters, and each type of waste is clearly identified with six digits. Chapter number 17 corresponds to C\&D waste.

The proposed waste classification system distinguishes three groups of waste within CW with common features: a) waste, mostly soil that is generated from the excavations prior to construction, b) waste due to the remains during the execution of the building elements and c) waste that involves packaging of the products and materials that are supplied to the works. Each of them is clearly different from the others, either from the management point of view at the work stage or their eventual treatment. Soil and remains are mainly identified in chapter number $17 \mathrm{EWL}$ and packaging waste comes under category number $15 \mathrm{EWL}$.

The soil group is structured as paragraph 5 of chapter 17 of the list. Although the EWL considers three types: soil and stones, dredging spoil and track ballast, with or without dangerous substances, the first type is usually the most common in the construction of buildings. There is also other waste which could be generated during the early stages of the work, such as plants, trees and bushes that come from the site cleaning that may be considered as park and garden waste within municipal waste (Chapter 20). During the execution of mortar and concrete at the construction site, waste sand, gravel and aggregates are also generated.

The remains group is structured according to chapter number 17 of the EWL. Seven types of waste can be distinguished, each of them getting similar treatment: concrete and ceramic materials of a stony inert nature; wood, glass and plastic, getting similar treatment to others that come from the domestic sector; tar and tarmacs (these being different because of their toxic nature); metals; insulating materials (making a distinction between the ones containing asbestos and the ones that do not); gypsum-based construction materials and lastly other C\&D waste. There is also other waste which could be generated in construction works contemplated in other chapters from the list as waste from the supply and use of coatings (paints and varnishes), adhesives, and sealants, (Chapter 08) or they could even be mixed with municipal waste (Chapter 20).

The packaging waste group is structured according to chapter number 15 of the EWL. It is classified according to the material it is made of, differing primarily between: cardboard 
containers (cardboard boxes mainly), plastic ones, wooden ones (pallets mainly) and metallic containers (mainly cans).

Among soil, remains and packaging waste there could also be materials and substances that may include some dangerous features: concrete additives (flammable), adhesives, sealants and mastic (flammable, toxic or irritant), tar emulsions (toxic, carcinogenic), asbestos-based materials in the form of inhalable fibre (toxic, carcinogenic), wood treated with fungicides, pesticides, etc (toxic, ecotoxic, flammable), coatings of halogenated flame retardants (ecotoxic, toxic, carcinogenic), equipment with PCBs (ecotoxic, carcinogenic), mercury lighting (toxic, ecotoxic), systems with CFCs, gypsum-based elements (possible source of sulphide in landfills, toxic, flammable), containers/packaging that have contained dangerous substances (solvents, paints, adhesives, etc.).

If the waste fulfils at least one criterion for danger, it is considered hazardous and is marked with an asterisk "*". In Spain, the National Decree 105/2008 (Spanish Government - Ministry of the Presidency, 2008) requires in rehabilitation and demolition projects the incorporation within the WMS of an Inventory of Hazardous Waste which will be generated by the execution of works. On new building construction it is not mandatory. Such waste must not be mixed with other waste and must be handled by authorised managers.

The proposed methodology also indicates the appropriate management of each type of waste according to European guidelines. CW and hazardous waste must be managed according to Directive 2008/98/CE (European Parliament, 2008). Annex I indicates a nonexhaustive list of the disposal operations (from D 1 to D 15), and Annex II indicates a nonexhaustive list of the recovery operations (from $R 1$ to $R$ 13). Packaging waste must be managed also according to Directive 1994/62/EC (European Parliament, 1994) and Directive 2004/12/EC on packaging and packaging waste (European Parliament, 2004). In accordance with the principle of waste hierarchy, recovery option must be prioritised rather than the disposal option. CW must be separated, preferably in the place of origin to promote the recovery of waste. In particular, the Sixth Environment Action Programme 2002-2012 (European Community, 2002), calls for measures aimed at ensuring source separation, collection and recycling of priority waste streams. In line with that objective and as a means to facilitating or improving its recovery potential, waste should be collected separately if technically, 
environmentally and economically practicable, before undergoing recovery operations that deliver the best overall environmental outcome. All EU member states should encourage the separation of hazardous compounds from waste streams if necessary to achieve environmentally sound management. In the case of Spain, for example, it is also required to separate each fraction when they exceed the following amounts: concrete: $80 \mathrm{t}$, bricks, tiles, ceramic: $40 \mathrm{t}$, metal: $2 \mathrm{t}$, wood: $1 \mathrm{t}$, glass: $1 \mathrm{t}$, plastics: $0.5 \mathrm{t}$, paper and cardboard: $0.5 \mathrm{t}$, (Spanish Government - Ministry of the Presidency, 2008). Harzadous waste must be separated selectively in the work itself, and thus avoid contaminating other non-hazardous waste.

\subsection{Model analytical expressions}

The analytical expressions developed gives the quantity of waste expected in each building/sitework element number "i", as the addition of packaging waste, remains and soil coded according to the EWL. Two main variables are necessary (1) the amount of the building/sitework elements and their building materials and components, both their quantity and types and, (2) the transformations that these building materials and their packagings experience throughout the construction process. The first variable is obtained from the measurements and budget document of the project. The second variable is solved by means of certain transformation factors. These factors depend on the source and type of waste and the technology of the site: how materials are supplied to the site, how they are packed, how building componets are manufactured, how wastes are collected, which are the standards of quality in the execution of the work, etc... These can be obtained from construction database of a region and from data of the manufacturers and suppliers of the building products. These are statistical data and represents standard technology in a locality.

Waste expected in each system building/sitework elements number "j" is obtained as the addition of the packaging wastes, remains and soil generated in each building/sitework element "i" belonging to the system " $\mathrm{j}$ ". And finally the total packaging waste, remains and soil expected in the building is obtained by the sum of those expected in each system building/sitework elements. The analytical expressions used are given in Eq. (1).

$$
\mathrm{CW}_{\mathrm{B}}=\sum_{j} \mathrm{CW}_{\mathrm{SBEj}}=\sum_{j i} \mathrm{CW}_{\mathrm{BEi}}=\sum_{j i} \mathrm{CW}_{\mathrm{Pi}}+\sum_{j i} \mathrm{CW}_{\mathrm{Ri}}+\sum_{j i} \mathrm{CW}_{\mathrm{Si}}
$$


Where $\mathrm{CW}_{\mathrm{B}}$ is the volume of the $\mathrm{CW}$ expected in the building; $\mathrm{CW}_{\mathrm{SBEj}}$ is the volume of the $\mathrm{CW}$ expected in the system building element number "j"; $\mathrm{CW}_{\mathrm{BEi}}$ is the volume of the $\mathrm{CW}$ expected in the building element number "i"; $\mathrm{CW}_{\mathrm{Pi}}$ is the volume of the packaging waste expected in the building element number "i"; $\mathrm{CW}_{\mathrm{Ri}}$ is the volume of the remains expected in the building element number "i" and $\mathrm{CW}_{\mathrm{Si}}$ is the volume of the soil expected in the building element number "i".

The types and quantities of packaging waste generated by each building element and coded as the EWL are estimated by Eq. (2).

$$
\mathrm{CW}_{\mathrm{Pi}}=\sum_{k}(\mathrm{EWL})_{\mathrm{Pk}} \cdot \mathrm{Q}_{\mathrm{i}} \cdot \mathrm{F}_{\mathrm{P}} \cdot \mathrm{F}_{\mathrm{C}} \cdot \mathrm{F}_{\mathrm{I}}
$$

Where $\mathrm{CW}_{\mathrm{Pi}}$ is the volume of the packaging waste expected in the building element number "i"; $(E W L)_{P k}$ is the code of the packaging waste number " $k$ " according to the $E W L ; Q_{i}$ is the amount of building element number "i" in the unit of measurement of the project $(U), F_{P}$ is packaging waste factor, $F_{C}$ is conversion factor and $F_{1}$ is increased volume factor.

The types and quantities of remains generated by each building element and coded as the EWL are estimated by Eq. (3).

$$
\mathrm{CW}_{\mathrm{Ri}}=\sum_{k}(\mathrm{EWL})_{\mathrm{Rk}} \cdot \mathrm{Q}_{\mathrm{i}} \cdot \mathrm{F}_{\mathrm{R}} \cdot \mathrm{F}_{\mathrm{C}} \cdot \mathrm{F}_{\mathrm{I}}
$$

Where $\mathrm{CW}_{\mathrm{Ri}}$ is the volume of the remains expected in the building element number "i"; $(E W L)_{R k}$ is the code of the remain number "k" according to the $E W L ; Q_{i}$ is the amount of building element number "i" in the unit of measurement of the project $(U), F_{R}$ is remains factor, $F_{C}$ is conversion factor and $F_{1}$ is increased volume factor.

The types and quantities of soil generated by each building element and coded as the EWL are estimated by Eq. (4).

$$
\mathrm{CW}_{\mathrm{Si}}=\sum_{k}(\mathrm{EWL})_{\mathrm{Sk}} \cdot \mathrm{Q}_{\mathrm{i}} \cdot \mathrm{F}_{\mathrm{S}} \cdot \mathrm{F}_{\mathrm{C}} \cdot \mathrm{F}_{\mathrm{I}}
$$


Where $\mathrm{CW}_{\mathrm{Si}}$ is the volume of the soil expected in the building element number "i"; $(\mathrm{EWL})_{\mathrm{Sk}}$ is the code of the soil number " $\mathrm{k}$ " according to the EWL; $\mathrm{Q}_{i}$ is the amount of building element number " $i$ " in the unit of measurement of the project $(U), F_{S}$ is soil factor, $F_{C}$ is conversion factor and $F_{1}$ is increased volume factor.

The factors are defined below and the procedure to estimate them is also outlined. These consist of six decimal places and some examples are illustrated.

$F_{P}=$ Packaging waste factor. It is used when the supplied material is packaged. It transforms the amount of building material expressed in the project unit, into the amount of packaging waste expressed in real volume $\left(\mathrm{m}^{3}\right)$. This factor therefore depends on how the materials are packaged and is obtained by asking manufacturers and suppliers of products. For example, in Andalusia, cement is usually supplied into cardboard sacks and is measured in tons in the project. According to manufacturer data, the average volume of these sacks is $0.75 \mathrm{~m}^{3}$ per ton of cement. Therefore, in this case $F_{p}=0.750000$ which means that the volume taken up by the waste of cardboard sacks, if no increase of their volume is experimented, would be $0.75 \mathrm{~m}^{3}$ per ton of cement. Thus the proportion of wooden pallets, metal cans, plastics, cardboard boxes, etc. that exists for the unity of building material can be obtained. In the case of obtaining the mass of waste the datum requested from the supplier of the product would be the mass of packaging per amount of material supplied and would not need to apply the increased volumen factor.

$F_{R}=$ Remains factor. It is applied when the origin of the waste is due to losses (breakings, spills, off-cuts or damage...). It transforms the amount of building material expressed in the project measuring unit, into amount of remains to be taken away. This factor depends mainly on the type of material, the way that it is manufactured in the work and the quality standards in the execution. For example, a hollow brick has a remains factor greater than another solid brick; mortar executed in situ has greater remains than another executed at the factory and the quality standards in concrete to be reinforced are higher than in those which are not reinforced, so impacting on lower losses. This factor depends on the technology of the place and can be 
obtained from the losses of building materials considered in some construction databases. This is because traditionally these losses were reflected in the measurements and budget document of the project because they increase the price of the execution of each building element. For example in Andalusia, the BCCA estimates that the percentage of losses of concrete made on site to be reinforced is $4 \%$. Therefore $F_{R}=0.040000$.

$F_{S}=$ Soil factor. It is applied when the execution process of the building/sitework element generates soil. It transforms the amount of building/sitework element expressed in the project unit into amount of soil expressed in real volume $\left(\mathrm{m}^{3}\right)$. This is obtained from the dimensions of the building/sitework element that will be excavated according to project data. For example, in the case of a catch-basin with these dimensions: $51 \times 51 \mathrm{~cm}$, a depth of $100 \mathrm{~cm}$ and a wall thickness of $15.0 \mathrm{~cm}$, the volume of soil generated during the excavation is estimated at: $(0.51+0.30) \times(0.51+0.30) \times(1.00+0.20)$, therefore $F_{S}=0.787320$. Subsequently the soil sponge effect will be taken into account, by applying the increased volumen factor.

$F_{C}=$ Conversion factor. It is used when the measuring unit of the building material/packaging supplied is different from the measuring unit of the waste that is generated. It can therefore transform, the amount of building material expressed in the project measuring unit, in volume (if waste is obtained in volume), or in mass (if waste is obtained in mass). It is obtained from the units of measurement of the database prices. For example, the BCCA measures slabs according to their surface in square meters $\left(\mathrm{m}^{2}\right)$. In these cases Fc is the thickness of the slab in meters. In the case of estimating the mass of waste, this factor would be the density of concrete multiplied by the thickness of the slab.

$F_{1}=$ Increased volume factor. It is used because the measuring unit of the waste is expressed in apparent volume. Therefore, the increase of volume needs to be taken into consideration. It can transform the amount of waste (expressed in real volume) into apparent volume. This factor is statistical and is derived from construction databases. It depends mainly on the type of waste and its collection system. This is the factor that had traditionally been considered in the cost database in the set-aside, in which was taken into account the increase of volume due to the 
sponge effect. Another example would be the concrete made on site that experiences $10 \%$ of sponging according to BCCA once become waste, and therefore $F_{1}=1.100000$. This factor would not be necessary if the mass of waste is deemed instead of volume.

\subsection{Examples}

Table 2 shows an example. The first step is to identify the building element in the systematic structure of the construction process proposed and to obtain their quantity in the project. For example, one catch-basin $51 \times 51 \times 100 \mathrm{~cm}$ which is identified within the building system 03. Site mechanical utilities. The amount (Q) of materials necessary for the execution of the catch-basin is worked out from the measurements and budget document of the project expressed in the project unit. Sand, cement and gravel for making the concrete slab. Bricks necessary to execute the walls. Sand and cement for making the mortar on site, for executing the brick walls and for covering (data obtained from the BCCA).

Table 2

$C \& D$ waste expected in the execution of a catch-basin $51 \times 51 \times 100 \mathrm{~cm}$

Construction project in Andalusia

System element: 03. Site mechanical utilities

Building element: Catch-basin $51 \times 51 \times 100 \mathrm{~cm}$

\begin{tabular}{|c|c|c|c|c|c|c|c|}
\hline \multirow{2}{*}{$\begin{array}{l}\text { BUILDING } \\
\text { MATERIAL }\end{array}$} & \multirow{2}{*}{$\frac{\text { QUANTITY }}{\mathrm{Q}}$} & \multicolumn{3}{|c|}{ FACTORS } & \multicolumn{3}{|c|}{ WASTE GENERATED } \\
\hline & & $\mathrm{F}_{\mathrm{P}} / \mathrm{F}_{\mathrm{R}} / \mathrm{F}_{\mathrm{S}}$ & $F_{C}$ & $\mathrm{~F}_{\mathrm{I}}$ & $V\left(m^{3}\right)$ & EWL Code & type of waste \\
\hline $\mathrm{m}^{3}$ mortar & 0.112 & 0.030000 & 1.000000 & 1.100000 & 0.004 & 170101 & concrete \\
\hline $\mathrm{m}^{3}$ concrete & 0.129 & 0.060000 & 1.000000 & 1.100000 & 0.009 & 170101 & concrete \\
\hline $\mathrm{m}^{3}$ sand & 0.303 & 0.010000 & 1.000000 & 1.000000 & 0.003 & 170504 & soil \\
\hline \multirow[t]{3}{*}{ t cement } & 0.060 & 0.010000 & 0.666666 & 1.000000 & 0.000 & 170101 & concrete \\
\hline & 0.060 & 0.750000 & 1.000000 & 0.025000 & 0.001 & 150101 & cardboard \\
\hline & 0.060 & 0.025000 & 1.000000 & 1.100000 & 0.002 & 150103 & wooden pallet \\
\hline \multirow[t]{3}{*}{ m.u brick } & 0.176 & 0.050000 & 1.000000 & 1.250000 & 0.011 & 170102 & bricks \\
\hline & 0.176 & 0.250000 & 1.000000 & 1.100000 & 0.048 & 150103 & wooden pallet \\
\hline & 0.176 & 0.016000 & 1.000000 & 2.000000 & 0.006 & 150102 & plastic \\
\hline \multirow[t]{2}{*}{$\mathrm{u}$ auxiliary material } & 0.057 & 0.010000 & 1.000000 & 1.000000 & 0.001 & 150106 & mixed packaging \\
\hline & 0.027 & 0.010000 & 1.000000 & 1.000000 & 0.000 & 170904 & mixed waste \\
\hline u catch-basin & 1.000 & 0.787320 & 1.000000 & 1.200000 & 0.945 & 170504 & soil \\
\hline
\end{tabular}


The next step is to identify the waste generated according to the waste classification system proposed. Soil generated from the excavation and due to the losses of sand and gravel. Concrete due to losses of cement, mortar and concrete in their manufacture and handling. Bricks due to cracks in its storage, handling and execution of the walls. Mixed waste due to others, (those ones due, for example, to security elements as nets, handrails, scaffolding... or to control tests as test-tubes). Cardboard packaging in which cement is delivered, plastic packaging to protect the bricks supplied, wooden packaging for supplying the cement sacks and bricks, and, mixed packaging due to others (those due, for example, to packaging of auxiliary material), etc. This waste is quantified by applying the factors for the case of technology in Andalusia according to supplier's data and BCCA. Table 3 lists other examples of building elements common to Andalusian construction. CW of building system 03. Mechanical site utilities can be obtained by adding the CW of each type of catch-basins, collectors, tubes, etc... And finally, CW of the project can be obtained by adding the CW of building system 01 . Site clearing, 02. Site earth-work, 03. Site mechanical utilities, etc. up to 12. Paintings.

\subsection{Approach and usefulness of the model}

The approach of the model is corroborated by the way of obtaining the waste. The waste is equal to the volume (known and quantifiable data during the project phase) of the material supplied (known data from the project measurement document) multiplied by losses (statistical data which may be obtained from construction databases) and multiplied by volume increase (estimative data obtained from construction databases). Therefore, if the quantity obtained does not coincide with the actual amount of generated waste it is because some of the input data was incorrect, but not because the method is not valid. Likewise as the data used is highly viable as most of them are statistical data used in construction databases and thus contrasted with reality and long accepted, therefore the model seems to be a valid approach a priori.

One advantage of the method is that these factors depend on the technology of each site, and precisely this feature would allow detection of any change in technology on a site, simply requiring modification of the corresponding quantification factors to get back the waste 
generation ratios. For example, the effects on waste generation of a change in the packaging of a building material in a region could be assessed.

Another use of the model is that it allows evaluation of alternative construction procedures. For example, the effects on waste generation due to lack of modular coordination in paving. In this case, only the remains factor is the quantification factor that is affected and therefore must be evaluated.

\section{Results}

\subsection{Case study}

A case study is presented to compare data obtained with model and data on actual production of waste generated in order to test the validity of the model and show its usefulness in contrast to other studies. Results are not compared with data from other countries because construction waste depends on the technology of the place; therefore selected studies are concerning related construction procedures as similar as possible. The model was applied to a standard dwelling in Andalusia. It was a four floor 26 social housing building, built and promoted by a local authority developer, the Empresa Publica de Suelo en Andalucía EPSA (Andalusian Land Public Enterprise). Their specifications (surface, typology, functional aspects, materials, building elements, etc.) were those normally used in Andalusia: footings, reinforced concrete, reinforced beams, brick closings, flat roof, aluminum carpentry on the exterior, etc...

Over 200 building elements were identified in the project. Their factors were obtained by studying over 20 dwellings with similar typological characteristics. The types and quantities of waste coded according to EWL were obtained for each building/sitework element by applying the model. This table is not provided in this paper in order to avoid excessive length because of its complexity and because the absence of available data by building elements that did not serve to compare data. The tables that are provided comprise waste in ways which allow comparison with available data. Table 3 sumarises $\mathrm{CW}$ by building element. Table 4 presents pooled data by type of waste code EWL and Table 5 shows the waste grouped by each system building/sitework elements. 
Table 3

Construction waste expected in building/sitework elements in Andalusian buildings

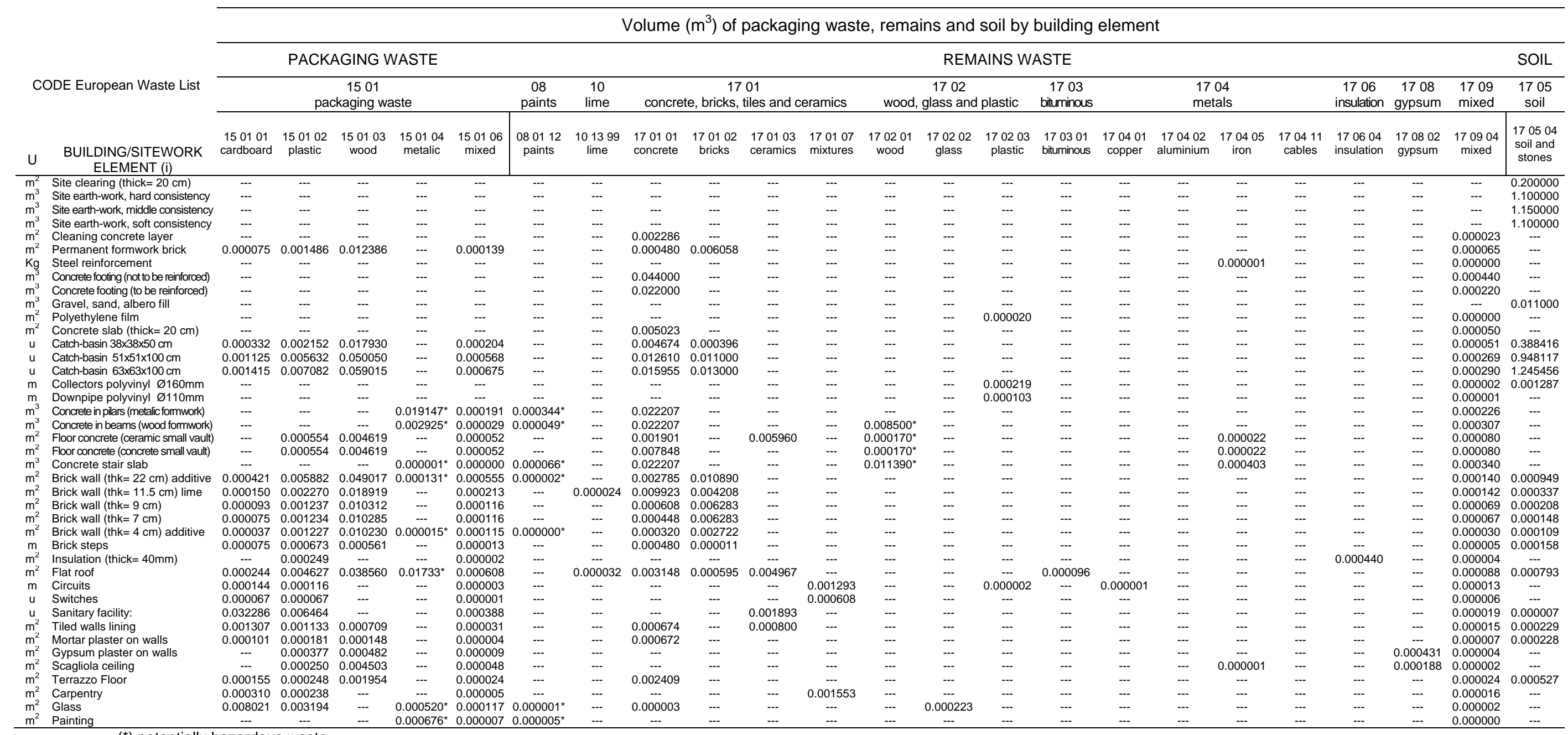

$\left.{ }^{*}\right)$ potentially hazardous waste 
Table 4

CW expected encoded according to the EWL and managed according to Directive 2008/98/CE

\begin{tabular}{|c|c|c|c|c|c|c|c|c|c|c|c|c|}
\hline \multicolumn{13}{|c|}{ 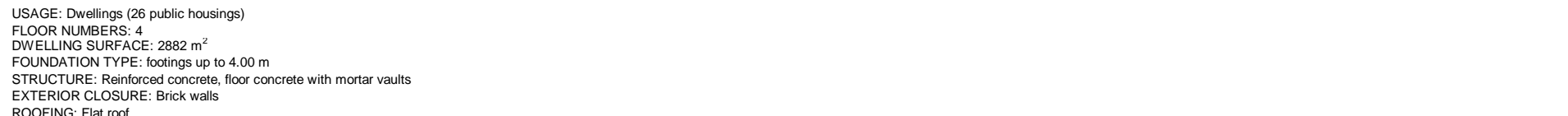 } \\
\hline $\begin{array}{l}\text { CODE } \\
\text { EUROPEAN } \\
\text { WASTE LIST }\end{array}$ & $\begin{array}{c}\text { TYPE OF WASTE } \\
\text { (* waste that } \\
\text { may be hazardous) }\end{array}$ & $\begin{array}{c}\text { CONTRACTOR } \\
\text { Waste } \\
\text { Waste } \\
2882 \mathrm{~m}^{2} \\
\end{array}$ & $\begin{array}{c}\mathrm{m}^{3} \\
\text { Waste } \\
2882 \mathrm{~m}^{2}\end{array}$ & $\begin{array}{l}\mathrm{m}^{3} \\
\text { Waste } \\
\text { per } \mathrm{m}^{2}\end{array}$ & $\begin{array}{l}\text { MODEL } \\
\text { \% } \\
\text { by toal } \\
\text { waste w }\end{array}$ & $\begin{array}{c}\% \\
\begin{array}{c}\% \\
\text { by waste } \\
\text { without soil }\end{array}\end{array}$ & $\begin{array}{l}\% \\
\text { by group } \\
\text { of waste }\end{array}$ & $\begin{array}{l}\text { OTH } \\
m^{3} \text { Waste } \\
\text { per m }{ }^{2}\end{array}$ & $\begin{array}{c}\text { HER STUDD } \\
(\text { b) } \\
\%\end{array}$ & $\begin{array}{l}\text { Es }(c) \\
\mathrm{m}^{3} \text { Waste } \\
\text { per m } \mathrm{m}^{2} \\
\end{array}$ & $\begin{array}{l}\text { Recovery } \\
\text { Disposal } \\
\text { Operation }\end{array}$ & MAIN SOURCE \\
\hline 15 & \multicolumn{2}{|l|}{ PACKAGING WASTE } & 235.91 & 0.0819 & 19.52 & 58.97 & 100.00 & 0.0800 & no data & 0.0554 & & at the site of collection and supply of materials \\
\hline 150101 & $\begin{array}{l}\text { paper and cardboard } \\
\text { packaging }\end{array}$ & no data & 25.86 & 0.0090 & 2.14 & 6.46 & \multicolumn{2}{|c|}{$10.960 .0040(5 \%)$} & 0.30 & no data & R3/D5 & supply of cement, lime, electric equipment, sanitary equipment, tiles, etc ... \\
\hline 150102 & plastic packaging & no data & 30.90 & 0.0107 & 2.56 & 7.72 & \multicolumn{2}{|c|}{$13.100 .0080(10 \%)$} & no data & no data & R3/D5 & supply of ceramic elements, gypsums, plaster casts, ... \\
\hline 150103 & wooden packaging & 153.00 & 164.97 & 0.0572 & 13.65 & 41.24 & \multicolumn{2}{|c|}{$69.930 .0640(80 \%)$} & no data & no data & R3/R1 & wooden pallets \\
\hline 150104 & metallic packaging ${ }^{*}$ & no data & 11.83 & 0.0041 & 0.98 & 2.96 & \multicolumn{2}{|c|}{$5.010 .0040(<5 \%)$} & no data & no data & R4/D5 & paint cans, if contains dangerous substances must be coded $150111^{\star}(R 3 / R 4)$ \\
\hline 150106 & mixed packaging & no data & 2.35 & 0.0008 & 0.19 & 0.59 & 1.00 & no data & no data & no data & R3/D5 & if contains dangerous substances must be coded $150110^{*}$ \\
\hline 17 & \multicolumn{2}{|l|}{ REMAINS } & 164.07 & 0.0569 & 13.58 & 41.02 & 100.00 & 0.0450 & no data & 0.0524 & & losses, breakages on site, collection of materials and remains during execution \\
\hline 080112 & waste paint and varnish* & no data & 0.11 & 0.0000 & 0.01 & 0.03 & 0.07 & no data & no data & no data & $\mathrm{R} 5 / \mathrm{D5}$ & $\begin{array}{l}\text { Concretet releases, aditives, plasticizers, paints, varnishes...., if contains organic solvents or } \\
\text { other dangerous substances must be coded } 080110^{1 *}(\mathrm{R} 13)\end{array}$ \\
\hline 080410 & $\begin{array}{l}\text { waste adhesives and } \\
\text { sealants }\end{array}$ & no data & 0.00 & 0.0000 & 0.00 & 0.00 & 0.00 & no data & no data & no data & R5/D5 & $\begin{array}{l}\text { achesesive pastes, sealants... if contains organic solvents or other dangerous substances must } \\
\text { be coded } 080400^{*}(\text { R13) }\end{array}$ \\
\hline 101399 & lime & no data & 0.76 & 0.0003 & 0.06 & 0.19 & 0.46 & no data & no data & no data & R5/D15 & lime mortar \\
\hline 170101 & concrete & no data & 81.13 & 0.0282 & 6.71 & 20.28 & 49.45 & 0.0244 & 12.00 & no data & R5/D15 & concrete, mortar, cement, mortar vaults, terrazzo floors, concrete block,.. \\
\hline 170102 & bricks & no data & 48.46 & 0.0168 & 4.01 & 12.11 & 29.54 & 0.0175 & 54.00 & no data & R5/D15 & bricks walls, partitions, screed bricks,... \\
\hline 170107 & $\begin{array}{l}\text { mixtures of concrete, bricks, } \\
\text { tiles and ceramics }\end{array}$ & no data & 22.26 & 0.0077 & 1.84 & 5.56 & 13.57 & 0.0011 & no data & no data & $\mathrm{R} 5 / \mathrm{D} 15$ & $\begin{array}{l}\text { opening in walls to incorporate facilities, to incorporate waterproof sheeting, punctual birick } \\
\text { walls demolitions, }\end{array}$ \\
\hline 170201 & $\operatorname{wood}^{*}$ & no data & 3.23 & 0.0011 & 0.27 & 0.81 & 1.97 & & 4.00 & no data & R3/D15 & $\begin{array}{l}\text { remains of timber formwork, if contains dangerous substances must be coded } 170204^{*} \\
(\mathrm{R} 3),(\mathrm{R} 5),(\mathrm{Dg})\end{array}$ \\
\hline 170202 & glass & no data & 0.12 & 0.0000 & 0.01 & 0.03 & 0.07 & & 0.05 & no data & R5/D15 & broken glass \\
\hline 170203 & plastic & no data & 0.08 & 0.0000 & 0.01 & 0.02 & 0.05 & Others & 1.50 & no data & R3/D15 & polyethylene sheets under slabs, losses of polyvinyl chloride pipes, etc ... \\
\hline 170302 & bituminous mixtures* & no data & 0.13 & 0.0000 & 0.01 & 0.03 & 0.08 & 0.0007 & 5.00 & no data & $\mathrm{R} 3 / \mathrm{D} 15$ & $\begin{array}{l}\text { asphalt waterproofing in flat roots. If contains coal tar must be coded } 170300^{*}(\mathrm{R} 13) \text { and ifit } \\
\left.\text { is made of coal tar and tarred products must be coded } 170303^{*}(R 13)\right)\end{array}$ \\
\hline 170401 & copper, bronze, brass & no data & 0.01 & 0.0000 & 0.00 & 0.00 & 0.01 & & 2.50 & no data & R4/D5 & copper pipes \\
\hline 170405 & iron and steel & 0.10 & 0.07 & 0.0000 & 0.01 & 0.02 & 0.04 & & & no data & $\mathrm{R} 4 / \mathrm{D5} 5$ & losses of trussings, reinforcements, armatures, metalic shores,... \\
\hline 170604 & insulation materials* ${ }^{*}$ & no data & 2.19 & 0.0008 & 0.18 & 0.55 & 1.33 & & no data & no data & R3/D5 & $\begin{array}{l}\text { insulation in walls and ceilings, made of expanded polystyrene, mineral fiber....If contains } \\
\text { asbestos must be coded } 170601^{\star}\end{array}$ \\
\hline $170605^{*}$ & $\begin{array}{l}\text { construction materials } \\
\text { contanining asbestos }\end{array}$ & no data & 0.05 & 0.0000 & 0.00 & 0.01 & 0.03 & no data & no data & no data & R13/D15 & asbestos-cement pipes \\
\hline 170802 & gypsum* & no data & 3.83 & 0.0013 & 0.32 & 0.96 & 2.33 & no data & 0.20 & no data & $\mathrm{R} 5 / \mathrm{D} 15$ & $\begin{array}{l}\text { coat plasters in walls, in ceilings, scagliola ceilings... if contains dangerous substances must } \\
\text { be coded } 170801 \times(R 1, R 4, R 5)\end{array}$ \\
\hline 170904 & $\begin{array}{l}\text { mixed construction and } \\
\text { demolition wastes }^{*}\end{array}$ & 269.50 & 1.64 & 0.0006 & 0.14 & 0.41 & 1.00 & no data & 11.00 & no data & R5/D5-D9 & $\begin{array}{l}\text { If contains mercury, } P C B \text { or other dangerous substances must be cood } \\
02^{*} \text { or } 17090^{*} \text { respectively }(R 1, R 4, R 5)\end{array}$ \\
\hline 1705 & SOIL AND STONES & 825.60 & 808.30 & 0.2805 & 66.90 & & 100.00 & no data & no data & 0.2000 & & at the beginning of the work during site clearing and excavations \\
\hline 010409 & waste sand & no data & 7.46 & 0.0026 & 0.62 & no data & 0.92 & no data & 4.00 & no data & $\mathrm{R} 5 / \mathrm{D} 15$ & aggregates for the execution of mortars and concrete in situ \\
\hline 170504 & soil and stones (site-clearing) & no data & 180.00 & 0.0625 & 14.90 & no data & 22.27 & no data & Stone & no data & R3/D15 & \multirow{4}{*}{ 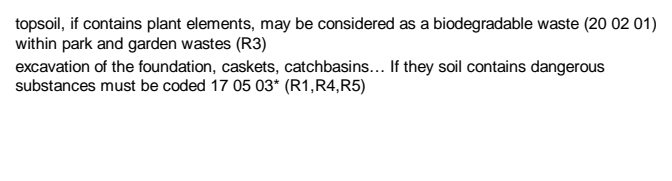 } \\
\hline \multirow[t]{3}{*}{170504} & soil and stones (earth-works)* & 825.60 & 620.84 & 0.2154 & 51.38 & no data & 76.81 & no data & 5.00 & no data & \multirow[t]{3}{*}{ Reuse } & \\
\hline & $\begin{array}{l}\text { TOTAL CW } \\
\text { without soil }\end{array}$ & 0.00 & 399.98 & 0.1388 & 33.10 & & & 0.1250 & no data & 0.1078 & & \\
\hline & $\begin{array}{l}\text { TOTAL CW } \\
\text { with soil }\end{array}$ & 825.60 & 1208.28 & 0.4193 & 100.00 & & & no data & no data & 0.3076 & & \\
\hline
\end{tabular}

Study (a) Construction of buildings in Catalonia, ITeC (1994)
Study (b)
C\&D waste composition in a landfil in Madrid (SPanish Government - Ministry of the Environment, 2001)
Study (c) Construction and demolition of 100 dwelling buildings in Seville (Solis et al., 2009). 
Table 5

$\mathrm{CW}$ expected in the project of a dwelling by building system

USAGE: Dwellings (26 public housing)

FLOOR NUMBERS: 4

DWELLING SURFACE: $2882 \mathrm{~m}^{2}$

FOUNDATION TYPE: footings up to $4.00 \mathrm{~m}$

STRUCTURE: Reinforced concrete, floor concrete with mortar vaults

EXTERIOR CLOSURE: Brick walls

ROOFING: Flat roof

CONSTRUCTION WASTE

\begin{tabular}{|c|c|c|c|c|c|c|c|c|c|c|c|c|c|}
\hline \multirow{4}{*}{$\begin{array}{l}\text { SYSTEM BUILDING/SITEWORK } \\
\text { ELEMENTS }\end{array}$} & \multicolumn{2}{|c|}{ PACKAGING WASTE } & \multicolumn{3}{|c|}{ REMAINS } & \multicolumn{3}{|c|}{ SOIL } & \multicolumn{3}{|c|}{ TOTAL } & \multicolumn{2}{|r|}{ Study (c) } \\
\hline & $\mathrm{m}^{3}$ & $m^{3}$ & $\%$ & $\mathrm{~m}^{3}$ & $\mathrm{~m}^{3}$ & $\%$ & $\mathrm{~m}^{3}$ & $\mathrm{~m}^{3}$ & $\%$ & $\mathrm{~m}^{3}$ & $\mathrm{~m}^{3}$ & $\%$ & $m^{3}$ \\
\hline & Waste & Waste & & Waste & Waste & & Waste & Waste & & Waste & Waste & & Waste \\
\hline & $2882 \mathrm{~m}^{2}$ & per $\mathrm{m}^{2}$ & & $2882 \mathrm{~m}^{2}$ & per $\mathrm{m}^{2}$ & & $2882 \mathrm{~m}^{2}$ & per $\mathrm{m}^{2}$ & & $2882 \mathrm{~m}^{2}$ & per $\mathrm{m}^{2}$ & & per $\mathrm{m}^{2}$ \\
\hline 01 SITE CLEARING & 0.00 & 0.0000 & 0.00 & 0.00 & 0.0000 & 0.00 & 180.00 & 0.0625 & 22.27 & 180.00 & 0.0625 & 14.90 & no data \\
\hline 02 SITE EARTH-WORK & 0.00 & 0.0000 & 0.00 & 0.00 & 0.0000 & 0.00 & 569.20 & 0.1975 & 70.42 & 569.20 & 0.1975 & 47.11 & 0.2000 \\
\hline 03 SITE MECHANICAL UTILITIES & 3.21 & 0.0011 & 1.36 & 1.51 & 0.0005 & 0.92 & 51.64 & 0.0179 & 6.39 & 56.36 & 0.0196 & 4.66 & 0.0006 \\
\hline 04 FOUNDATION & 10.15 & 0.0035 & 4.30 & 24.33 & 0.0084 & 14.83 & 1.50 & 0.0005 & 0.19 & 35.98 & 0.0125 & 2.98 & 0.0116 \\
\hline 05 STRUCTURE & 21.14 & 0.0073 & 8.96 & 40.81 & 0.0142 & 24.87 & 0.00 & 0.0000 & 0.00 & 61.95 & 0.0215 & 5.13 & 0.0217 \\
\hline 06 MASONRY & 118.32 & 0.0411 & 50.15 & 52.27 & 0.0181 & 31.86 & 3.30 & 0.0011 & 0.41 & 173.89 & 0.0603 & 14.39 & 0.0381 \\
\hline 07 ROOFING & 18.08 & 0.0063 & 7.66 & 7.76 & 0.0027 & 4.73 & 1.20 & 0.0004 & 0.15 & 27.04 & 0.0094 & 2.24 & 0.0042 \\
\hline 08 SERVICES & 17.85 & 0.0062 & 7.57 & 18.66 & 0.0065 & 11.37 & 0.00 & 0.0000 & 0.00 & 36.51 & 0.0127 & 3.02 & 0.0039 \\
\hline 09 COATINGS & 31.71 & 0.0110 & 13.44 & 16.93 & 0.0059 & 10.32 & 1.46 & 0.0005 & 0.18 & 50.10 & 0.0174 & 4.15 & 0.0198 \\
\hline 10 CARPENTRY & 0.36 & 0.0001 & 0.15 & 1.59 & 0.0006 & 0.97 & 0.00 & 0.0000 & 0.00 & 1.95 & 0.0007 & 0.16 & 0.0016 \\
\hline 11 GLASS & 6.80 & 0.0024 & 2.88 & 0.14 & 0.0000 & 0.09 & 0.00 & 0.0000 & 0.00 & 6.94 & 0.0024 & 0.57 & 0.0008 \\
\hline 12 PAINTINGS & 8.28 & 0.0029 & 3.51 & 0.07 & 0.0000 & 0.04 & 0.00 & 0.0000 & 0.00 & 8.35 & 0.0029 & 0.69 & 0.0053 \\
\hline TOTAL & 235.91 & 0.0819 & 100.00 & 164.07 & 0.0569 & 100.00 & 808.30 & 0.2805 & 100.00 & 1208.28 & 0.4193 & 100.00 & 0.3076 \\
\hline
\end{tabular}

Study (c) Construction and demolition of 100 dwelling buildings in Seville (Solis et al., 2009) 


\subsection{Actual available data}

According to contractor data it was possible to obtain the actual amount of 4 waste fractions: soil, mixed waste, wooden pallets and steel. The other fractions have been compared with available waste data obtained from Section 2.3: data obtained by studying buildings in Catalonia (study a), the composition of waste in a landfill in Madrid (study b), and finally, the construction and demolition of 100 dwelling buildings in Seville (study c).

One of the main difficulties was that these studies only provide their data in this way and do not break down their data as the model does. Despite the lack of data and the various concepts considered in the quantities of waste, the results obtained by these other studies were included in Tables 4 and 5. Cells that indicate "no data" is because it was not possible to obtain this information.

\section{Discussion}

\subsection{Estimation of construction waste}

A rate of CW (without soil) generation of $0.1388 \mathrm{~m}^{3} / \mathrm{m}^{2}$ was obtained. Although it meant $95 \%$ of the actual amount of waste, it is considered a value acceptable for the purpose of this study.

\subsection{Composition and quantification of packaging waste}

A rate of packaging waste generation of $0.0819 \mathrm{~m}^{3} / \mathrm{m}^{2}$ was obtained. This rate was similar (102\%) to the data considered as the most reliable in Spain, study (a). The packaging waste obtained meant a greater volume (59\%) than the remains volume (41\%), in the same way as in study (a). According to Table 5 more than half of packaging waste was generated during the phases of masonry and coatings such as the study (c). Five fractions were distinguished in order from the largest to the smallest volume generated: 70\% (15 0103 ) wooden packaging; 13\% (15 01 02) plastic packaging; 11\% (15 0101$)$ cardboard packaging; 5\% (15 0104$)$ metalic packaging and 1\% (15 0106$)$ mixed packaging. The percentages obtained do not show a large spread over the study (a). Wooden pallets represents $108 \%$ of the actual amount of pallets and meant a large portion such as the study (a) (80\%). 


\subsection{Composition and quantification of remains}

A rate of remains generation of $0.0569 \mathrm{~m}^{3} / \mathrm{m}^{2}$ was obtained. This rate is equal to $126 \%$ the amount considered as the most reliable in Spain, study (a), and closer still (109\%) to the study (c). According to Table 5 more than half of remains were generated during the phases of masonry and structure such as the study (c).

The percentages and composition of the remains obtained are also similar to the other studies as follows. Most of remains waste was a stony fraction (95\%), as happens in study (a) $97 \%$, and study (b) $75 \%$. Five stony fractions were distinguished in order from the largest to the smallest volume generated: 49\% (17 0101 ) concrete; 30\% (17 0102 ) bricks; 14\% (17 0107 ) mixtures of concrete, bricks, tiles and ceramics; 1\% (17 09 04) mixed construction and demolition wastes and 0.5\% (10 13 90) lime. Concrete waste exceeds ceramic waste such as the study (a).

A small amount of waste with treatment similar to MSW (2.14\%) was also obtained with percentage similar to study (a), 2.69\%. Five MSW fractions were distinguished in order from the largest to the smallest volume generated: $1.97 \%$ (17 02 01) wood (from timber formwork mainly); 0.07\% (17 02 02) glass; 0.05\% (17 02 03) plastic; 0.04\% (17 0405$)$ iron and steel and finally, 0.01\% (17 0401$)$ copper, bronze and brass.

\subsection{Composition and quantification of soil}

Remains and packaging accounted for $33 \%$, and the soil obtained was the waste of the greatest volume (67\%). A rate of soil generation of $0.2805 \mathrm{~m}^{3} / \mathrm{m}^{2}$ was estimated. It meant $98 \%$ of the actual amount of soil. Three soil fractions with different nature were distinguished: $77 \%$ (17 05 04) soil from the excavation-work; $22 \%$ (17 05 04) soil from the site-clearing, the top layer and 1\% (01 04 09) waste sand, gravel and aggregates.

Although most of this waste was generated during the first three phases of work, the site clearing, site earth-works and site mechanical utilities, during the execution of mortars or concretes on site, in the phases of foundations, masonry, roofing and coatings, waste sand, gravel and aggregates were also generated. 


\subsection{Composition and quantification of harzadous waste}

Among packaging waste and remains materials were obtained subsatnces that might include some dangerous features. None of the baseline studies nor the contractor provides data on hazardous waste. Metal cans which contained hazardous waste (paints, varnishes, sealants, solvents, adhesives etc... with dangerous substances) were considered hazardous waste. It represented about $5 \%$ of total packaging waste and were classified as $150111^{*}$.

The remains most likely to contain dangerous substances and to be considered as potentially hazardous waste represented a small fraction (about $5 \%$ of total remains) and were mainly in order from the largest to the smallest volume generated: $2.33 \%$ (17 0802$)$ gypsum, if it contains dangerous substances it might be coded $170801^{*} ; 1.97 \%$ (17 0201 ) wood, mainly from formworks, may contain losses of release agents, if it contains dangerous substances it might be coded $170204 * ; 1.33 \%$ (17 0604 ) insulation materials, if it contains asbestos it might be coded $170601^{*}$. 0.08\% (17 0302 ) bituminous mixtures, if it contains coal tar it might be coded $170301^{*}$ and if it is made of coal tar and tarred products it might be coded $170303^{*}$; 0.07\% (08 01 12) waste paint and varnish, if it contains organic solvents or other dangerous substances it might be coded 0801 11*; 0.03\% (17 06 05*) construction materials containing asbestos; $0.00 \%$ (08 04 10) waste adhesives and sealants, if it contains organic solvents or other dangerous substances it might be coded $080409^{\star}$. If mixed construction and demolition waste contains mercury lighting, equipment with $\mathrm{PCBs}$ or other dangerous substances as systems with CFCs they might be coded $170901^{*}, 170902^{\star}$ or $170903^{\star}$ respectively and managed as harzadous waste.

\subsection{Chances of recovery CW}

According to contractor data, only the fraction of wooden pallets and steel was recovered. Soil and the mixed fraction were transported to landfill. With the information obtained using the model the chances of $\mathrm{CW}$ recovery in the case study were greater than with the comparison studies as indicated below. Table 4 shows a column which mentions the main disposal and recovery options to be considered for each type of waste in accordance with European guidelines. One advantage of giving a detailed classification of construction waste is that the chances of recovery of waste may be increased. For example, the topsoil might be separated 
from the soil from the excavation-work, since it has a high value as compost. In this case $15 \%$ of total CW would be recovered. Most of the remains and packaging waste were also potentially recoverable as indicated below.

Packaging waste meant a greater volume than the remains volume. However, they had a higher degree of recyclability than the remains had because they ocured in the place of delivery and collection of material, facilitating their subsequent separation and selective removal. Agreements with suppliers of building materials were proposed for their withdrawal from the work. In the case study only the removal of wooden pallets would allow recovery $41 \%$ of total CW (without soil). In fact, this was the only fraction of packaging waste that was actually selectively recovered.

Remains were of a heterogeneous nature as they were generated at the worksite causing a laborious process of selective separation because they usually appeared mixed and linked with other materials. Separating the large stony fraction $(>95 \%)$ of that other small amount $(<5 \%)$ of $\mathrm{CW}$ similar to domestic waste is fundamental. This stony fraction might be managed as R 5 recycling/reclamation of other inorganic materials, and reused as fill material for example. In the case study only the selective separation of the stony fraction made of concrete, ceramic, lime, mixtures and sand generated during the implementation of mortars would have allowed recovery $44 \%$ of total waste $\mathrm{CW}$ (without soil).

If these two main measures considered in the project would have been technically and economically viable on site, it would have allowed recovery of at least $85 \%$ of the CW. If an average CW density of $1.00 \mathrm{t} / \mathrm{m} 3$ is considered, this would have meant a rate well above the $70 \%$ of the EU goal.

\subsection{Chances of prevent CW}

With the information obtained using the model the chances of CW prevention in the case study were greater than with the comparison studies as shown below. In the case study soil was the waste that took up the most volume (67\%). Because of their considerable volume, the cost of removal to landfill has traditionally been considered in the measurements and budget document of the project. The European legislation on waste, recognising the need to reduce the amount of such waste to avoid filling landfills, encourages reusing this soil as fill material on- 
site. In the case study its reuse is proposed and it is not considered as waste (European Parliament, 2008). If soil is contaminated, it must be coded $170503^{*}$, reuse is forbidden and it must be handled by a hazardous waste manager.

In the case study hazardous waste could have represented up to $6 \%$ of $\mathrm{CW}$ (without soil). The model allows technicians to adopt building elements in the project that do not generate hazardous waste. For example, the case study considered in the project coal tar asphalt waterproofing in flat roofs, wich generated harzadous waste $\left(170301^{\star}\right)$ that should have been replaced in the project by waterproofing without coal tar. Another example is that according to Table 3 in the brick walls it would have been desirable to replace the organic plasticisers in mortars by others inorganic like lime. In this case not only the hazardous remains would have been eliminated but also the hazardous packaging.

Alternative building/sitework elements that generate less construction waste could also have been used in the project, providing that technical and economic conditions permit. A simple example would be if in the case study instead of adopting a foundation by footings in the project, a foundation by piles had been considered. A prori it would have generated less soil. The building elements optimised during the design phase will also prevent the generation of waste. This is because the amount (Q) of materials needed to execute them that are considered in the analytical expressions will be lower. An example of this would be if in the case study the sections of the beams of the structure would have been optimised. Not only would fewer resources be consumed, concrete, iron, formworks, etc. but less waste would also be generated. Just as would happen with packaging waste. Those materials supplied with the least amount of packaging, will also generate less waste (provided the containers meet the minimum requirements for protection of these materials).

With all these measures envisaged for the project could eliminate a large amount of hazardous waste on site and reduce the volume of waste.

\subsection{Model validity}

In the case study only 4 waste fractions were separated on site. However, in the new works 9 fractions usually begin to be classified. The model allowed to distinguish 24 fractions of waste and to identify its origin during the project phase. The source of the waste was a datum with a 
high degree of reliability since it was obtained by studying the construction processes in building elements. The types of waste obtained had a high degree of reliability since they were identified from measurements of the project and packaging according to manufacturers' data. The estimated total amount of waste presented a deviation from the real value of $-5 \%$. As for the estimated quantities for each of the 24 waste fractions generally have had a spread of $\pm 10 \%$ compared to the actual values of contractor data and other studies. As existing dispersions are smaller than even among the other studies, then the model is currently considered a valid approach. In the future, as more knowledge is acquired in this field, the conditions for obtaining more reliable factors will be increased.

\section{Conclusions}

The current construction model is untenable. A large amount of resources is consumed and wasted, a considerable volume of waste is discharged in controlled or uncontrolled landfills recovering very little and finally there is still some ignorance on the actual amount of waste generated. Given the pressing need to change this construction model, the new and major challenge of the recent framework legislation on waste within the EU is to become a "recycling society".

The Spanish government is facing this primary challenge within a recent legislative framework in which the document of the project becomes a key-piece which main objective is the efficient management of C\&D waste. However, one of the major barriers to achieving this objective is the lack of knowledge about the source of their generation.

In order to meet the goals established within the framework of the EU and Spanish legislation, this paper has presented a model for quantifying waste in projects in a specific and detailed way detecting their source to allow technicians to assess alternative construction procedures to achieve their maximun prevention and recovery on site as shown in Figure 5. The model seems to be a valid approach because it is based on statistical quantification factors used in long accepted construction databases, and because the overall rates and percentages obtained in the case study are close to the contractor data and the few available Spanish data, without an increased dispersion that occurs even between these studies. With the information 
obtained in projects using the model, unlike others studies, the chances of prevention and recovery $\mathrm{CW}$ in projects will be promoted as shown below.

- The model provided a waste classification system according to the EWL. This list is scattered because as although it has a specific chapter for this kind of waste, chapter number 17 , there is other waste generated during construction works that is not covered in this chapter (for example, packaging waste, paints and varnishes, lime, plants, etc...). In the model it is grouped into three blocks: packaging waste, soil and remains, encompassing them all, and maintaining their coding under the EWL.

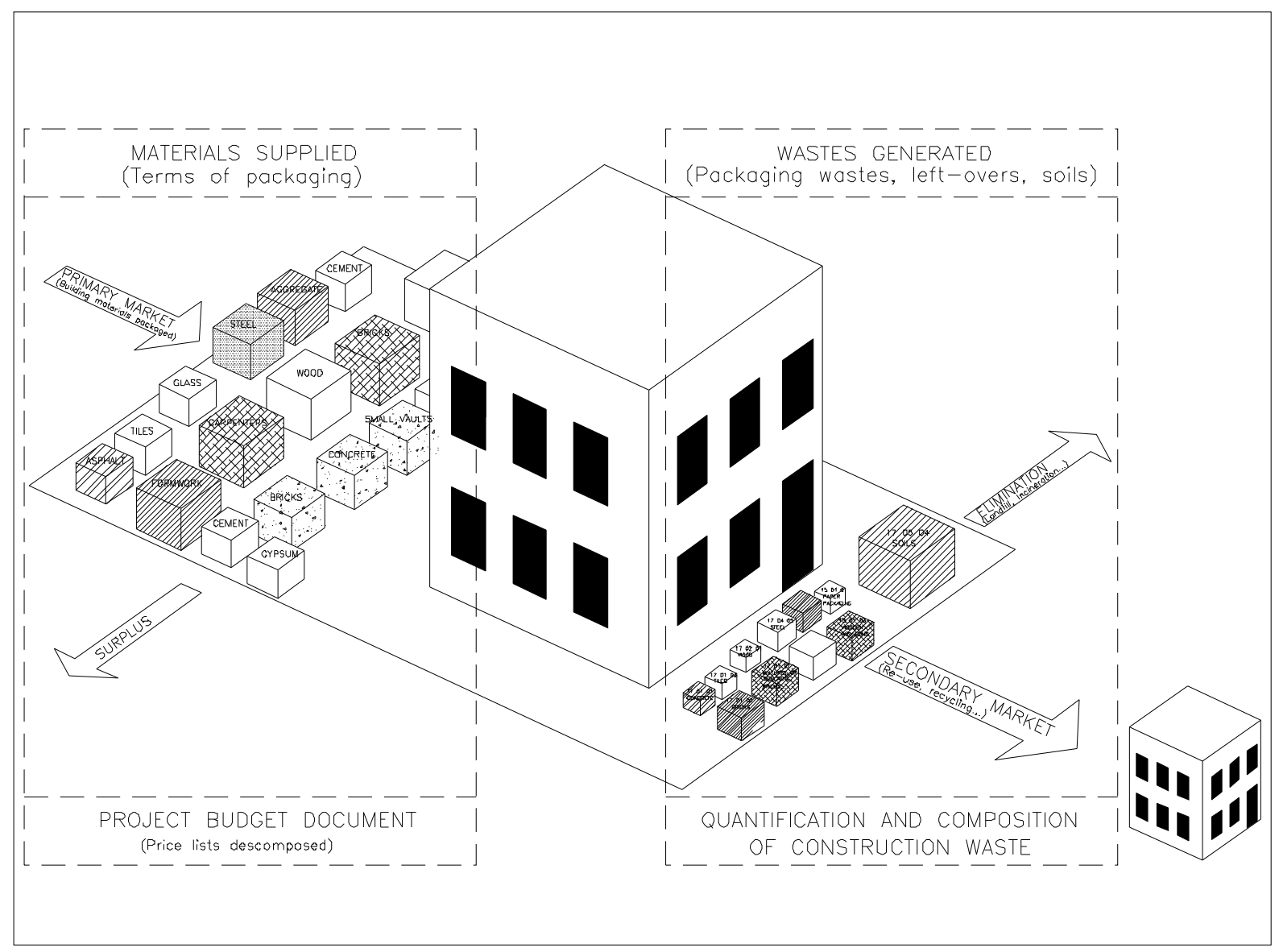

Fig. 5. Future scene of CW management with the proposed model.

- The prevention of C\&D waste in projects would be encouraged because waste is obtained for each building/sitework element allowing the origin and source of the waste to be detected. A utility of this modus operandi is that alternative building/sitework 
elements can be used that generate less construction waste in the project, provided that the technical and economic conditions permit, in order to prevent them.

- Hazardous waste can also be preventing. In the case study, for example, hazardous waste represented a small fraction (up to $5 \%$ of the remains). However, the main usefulness of the methodology is that it can detect the origin of the harzadous waste, and remove, using such an alternative construction procedure from the outset, the project, in order to prevent them.

- The model would promote architect's awareness of their role in prevent C\&D waste. Architects during the stage of the project could know the relationship between any decision and the composition and quantity of waste that is expected to be generated because of this decision.

- The chances of recovery C\&D waste in projects would be increased because the types and quantities of waste are estimated in detail and specifically for each type of project in order to develop a rational scheduling of the types and quantities of waste expected at the various stages of the construction process prior to the commencement of the works. In the case study the model identified and quantified 28 fractions of waste in over 200 building components during the project phase. It would allow program the type and size of the containers, the pick-up frequency on site, the treatment and final destination of each waste, etc... An assessment of the most effective actions to be carried out during the work can be made during the design stage. In the case study, for example, only two main measures, to remove the wooden pallets and separate the stony fraction could achieve recycle $85 \% \mathrm{CW}$, well above the EU target $70 \%$.

- This model can be exported to other countries, being able to obtain the quantification factors for any building/sitework element of any constructive characteristics and building materials. It may be used even in other types of buildings such as offices, industrial, educational, etc... Database could even be developed with a universal character of building elements and their types and quantities of construction waste. As it obtains the list of waste according to the EWL, it complies with its objectives: the protection of the environment and the establishment and good functioning of the home market within the EU, helping for making waste statistics and for waste transport. 
In the future, this model would allow progress in the study of C\&D waste in buildings. However, all these actions are of little use if they are not implemented. For this reason, training courses whose goal is to make future architects aware of the importance of their role are convenient. A change of mentality is necessary; waste must be regarded as a potential economic resource from the early stages of design in order to extend their life cycle. Legislation could establish a maximum index of waste generation by type of project, penalising those that exceed this. Architects for example could design waste-digesters building elements (fences, walls, sub-bases, covers, etc...). And the authorities could introduce a clause in their contract specifications for the procurement of projects with low rates of waste generation during construction, life and demolition of the building. These actions, in most cases technically feasible, may be economically beneficial over other options and therefore compelling to developers, contractors and builders as it would avoid unnecessary transport of waste disposal costs, waste of raw materials, etc... From the above, it can be concluded that with the future implementation of all this measures in projects, the change from the current untenable construction to another closer to an eco-efficient construction would be possible. 


\section{Acknowledgements}

The author is grateful to the Consejería de Vivienda y Ordenación del Territorio de la Junta de Andalucía (Department of Housing and Spatial Planning of the Government of Andalusia) for subsiding the Research Project "-CDWs = + ECO-efficiency. Waste Reduction in the Design and Construction of Dwellings in Andalucia", in which the tool with this method of quantification of waste is being implemented.

In addition the author wishes to thanks other institutions which promoted this research in previous years: La Dirección General de la Vivienda, la Arquitectura y el Urbanismo del Ministerio de Fomento (Directorate General of Housing, Architecture and Urban Planning of the Ministry of Public Works), Research Grant 1998; Fundación Aguas de Barcelona (Agbar Foundation), first runners-up contest for sustainable development thesis, 2001. Seville City Council, first prize urban environment, 2001; The Dirección General de Calidad y Evaluación Ambiental del Ministerio de Medio Ambiente (General Directorate of Quality and Environment Assessment of the Ministry of Environment), National Plan of Scientific Research, Development and Technological Innovation (2004-2007). And finally, thanks also go to Dr. S. Girón for her invaluable support. 


\section{References}

Andalusian Government - Dwelling Counseling, 2010. Base de Costes de la Construcción de Andalucía (BCCA) 2010 (Andalusian Construction Costs Database 2010). Consejería de Vivienda y Ordenación del Territorio de la Junta de Andalucía, Seville, Spain.<http://www.juntadeandalucia.es > (last viewed July 2010; currently only in Spanish).

Batayneh, M., Iqbal, M., Ibrahim, A., 2007. Use of selected waste materials in concrete mixes. Waste Management 27, 1870-1876.

BEDEC, 2010. Instituto de Tecnología de la Construcción de Cataluña (ITeC), Spain. $<w w w . i t e c . e s / n o u B e d e c . e>$.(last viewed July 2010; currently only in Spanish).

Begum, R.A., Siwar, C., Pereira, J.J., Jaafar, A.H., 2007. Factors and values of willingness to pay for improved construction waste management - A perspective of Malaysian contractors. Waste Management 27, 1902-1909.

Bergsdal, H., Bohne, R. A, Brattebo, H., 2007. Projection of construction and demolition waste in Norway. Journal of Industrial Ecology 11 (3), 27-39.

Bossink, B.A.G., Brouwers, H.J.H., 1996. Construction waste: quantification and source evaluation. Journal of Construction Engineering and Management ASCE 122 (1), 55-60.

Chandrakanthi, M., Hettiaratchi, P., Prado, B., Ruwanpura, J., 2002. Optimization of the waste management for construction projects using simulation. In: Proceedings of the 2002 Winter Simulation Conference, December 8-11, San Diego, California, 1771-1777.

Cochran, K., Townsend, T., Reinhart, D., Heck, H., 2007. Estimation of regional building-related C\&D debris generation and composition: Case study for Florida, US. Waste Management 27, 921-931.

Cochran, K.M., Townsend, T.G., 2010. Estimating construction and demolition debris generation using a materials flow analysis approach. Waste Management 30, 2247-2254.

Commission Decision 2000/532/EC of 3 May 2000 replacing Decision 94/3/EC establishing a list of wastes pursuant to Article 1(a) of Council Directive 75/442/EEC on waste and Council Decision 94/904/EC establishing a list of hazardous waste pursuant to Article 1(4) of Council Directive 91/689/EEC on hazardous waste (notified under document number C(2000) 1147). Official Journal of the European Union L226, 2000, 3-24. 
Commission Decision 2001/118/EC of 16 January 2001 amending Decision 2000/532/EC as regards the list of wastes (notified under document number C(2001) 108). Official Journal of the European Union L47, 2001, 1-31.

Construction Materials Recycling Association, 2005. Construction Materials Recycling Association, Chicago, Illinois. <http://www.cdrecycling.org/>.(last viewed July 2010).

Ekanayake, L.L., Ofori, G., 2000. Construction material waste source evaluation. In: Proceedings of the Second Southern African Conference on Sustainable Development in the Built Environment: Strategies for a Sustainable Built Environment, Pretoria, 23-25 August.

Elshkaki, A., van der Voet, E., Timmermans, V., Van Holderbeke., M., 2005. Dynamic stock modeling: A method for the identification and estimation of future waste streams and emissions based on past production and product stock characteristics. Energy 30 (8), 13531363.

European Economic and Social Committee, 1997. Opinion on "Sustainable development in building and housing in Europe", Official Journal of the European Union C355, 1997, 16-21.

European Community, 2002. Sixth Environment Action Programme 2002-2012 (Sixth EAP). Environment 2010: Our Future, Our Choice. European Community, Brussels, Belgium.

European Environmental Agency, 2007. Europe's environment - The fourth assessment/State of the environment Report No 1/2007.

European Parliament, 1994 - Directive 1994/62/EC of the European Parliament and of the council of 20 December 1994 on packaging and packaging waste. Official Journal of the European Union L365, 0010-0023.

European Parliament, 2004 - Directive 2004/12/EC of the European Parliament and of the Council of 11 February 2004 amending Directive 94/62/EC on packaging and packaging waste. Official Journal of the European Union L 047, 0026-0032.

European Parliament, 2008 - Directive 2008/98/CE of the European Parliament and of the council of 19 November 2008 on waste and repealing certain Directives. Official Journal of the European Union L312/,0003-0030.

Eurostat, 2009. European Communities. Statistics on focus. Kloek, W., Blumenthal, K. Environment and energy. Generation and treatment of waste. < http://epp.eurostat.ec.europa.eu/cache > (last viewed July 2010). 
Esin, T., Cosgun, N., 2006. A study conducted to reduce construction waste generation in Turkey. Building and Environment 42, 1667-1674.

Faniran, O.O., Caban, G., 1998. Minimizing waste on construction project sites. Engineering Construction and Architectural Management 5 (2), 182-188.

Fatta, D., Moll, S., 2003. Assessment of information related to waste and material flows. A catalogue of methods and tools. European Environment Agency, Copenhagen.

FIDAS, 2010. Foundation for the Research and Development of Architecture in Seville. http://www.fidas.es (last viewed July 2010; currently only in Spanish).

Franklin Associates, 1998. Characterization of Building Related Construction and Demolition Debris in the United States. EPA-530-R-98-010. US. Environmental Protection Agency, USA. Hendriks, C.F., Pietersen, H.S., 2000. Sustainable Raw Materials: Construction and Demolition Waste. RILEM Publication, Cachan Cedex, France.

Hsiao, T., Huang, Y., Yu, Y., Wernick, I. 2002. Modeling materials flow of waste concrete from construction and demolition wastes in Taiwan. Resources Policy Vol. 28 (1), 39-47.

Innes, S., 2004. Developing tools for designing out waste pre-site and onsite. In: Proceedings of Minimising Construction Waste Conference: Developing Resource Efficiency and Waste Minimisation in Design and Construction, October 21, New Civil Engineer, London, United Kingdom.

ITeC, 1994, Instituto de Tecnología de la Construcción de Cataluña (Institute of Construction Technology of Catalonia). Guía Técnica per al cumpliment del Decret 201/1994, de 26 de Juliol, regulador dels enderrocs y d'altres residus de la construccio. Barcelona, Spain.

ISO 6707-1, 2004. Building and civil engineering - Vocabulary. Part 1: General terms, International Organisation for Standardisation, Geneva, Switzerland.

Jaillon, L., Poon, C.S., Chiang, Y.H., 2008. Quantifying the waste reduction potential of using prefabrication in building construction in Hong Kong. Waste Management 29, 309-320.

Kofoworola, O.F., Gheewala, S.H., 2009. Estimation of construction waste generation and management in Thailand. Waste Management 29, 731-738.

Llatas, C., 2000. Residuos generados en la construcción de viviendas. Propuestas y evaluación de procedimientos y prescripciones para su minimización (Waste generated in the construction of dwellings. Proposals and assessment procedures and requirements for 
minimisation). Ph.D. Thesis. Departamento de Construcciones Arquitectónicas I, University of Seville, Spain.

Llatas, C., Huete, R., 2009. Construction waste management in projects within the framework of the Spanish legislation. Proceedings of the Twelfth International Waste Management and Landfill Symposium, Sardinia, 5-9 October 2009.

Llatas, C., Bizcocho, N., Huete, R., 2010. Methodological proposal for obtaining an achievement index waste in rehabilitation works in Andalusia. Proceedings of the Sustainable Building International Conference 2010, Madrid, 28-30 April 2010.

Müller, D. B., 2006. Stock dynamics for forecasting material flows - Case study for housing in the Netherlands. Ecological Economics 59 (1), 142-156.

National Institut of Standards and Technology, Canada, 1999. ASTM Uniformat II Elemental Classification for Building Specifications, Cost Estimating, and Cost Analysis.

Osmani, M., Glass, J., Price, A., 2006. Architect and contractor attitudes to waste minimisation. Waste Resour. Manage. 2 (1), 65-72.

Osmani, M., Glass, J., Price, A., 2007. Architects' perspectives on construction waste reduction by design. Waste Management 28, 1147-1158.

Poon, C.S., Yu, A.T.W., Jaillon, L., 2004. Reducing building waste at construction sites in Hong Kong. Construct. Manage. Econom. 22 (5), 461-470.

Ramírez-de-Arellano, A., Llatas, C., García, I., Linares, P., García, E.I., Escobar, M., Carnerero, M., Hernández, R., 2002. Retirada Selectiva de Residuos: Modelo de Presupuestación (Selective Waste Disposal: Estimate Model). Fundación Aparejadores, Seville, Spain.

Reinhart, D., Townsend, T., Heck, H., Chakrabarti, S., Cochran, K., Medeiros, S., 2003. Project Summary: Generation and composition of construction and demolition waste in Florida. Florida Center for Solid and Hazardous Waste Management. Gainesville, 123.

SMARTWasteTM, 2010. Building Research Establishment (BRE) Ltd., Watford, United Kingdom. <www.smartwaste.co.uk> (last viewed July 2010).

Solís, J., Marrero, M., Montes, M.V., Ramírez-de-Arellano, A., 2009. A Spanish model for quantification and management of construction waste. Waste Management 29, 2542-2548. 
Spanish Government - Ministry of the Environment, 2001. Plan Nacional de Residuos de Construcción y Demolición 2001-2006 (National C\&D Waste Plan 2001-2006). Ministry of the Environment, Madrid, Spain. BOE 166 of 12/7/2001.

Spanish Government - Ministry of the Environment, 2007. Borrador del Plan Nacional Integrado de Residuos 2007-2015 (Draft National Integrated Waste Plan 2007-2015). Ministry of the Environment, Madrid, Spain. < http:// www.mma.es.> (last viewed July 2010; currently only in Spanish).

Spanish Government - Ministry of the Presidency, 2008. Real Decreto 105/2008, de 1 de Febrero, por el que se Regula la Producción y Gestión de los Residuos de Construcción y Demolición (National Decree 105/2008, February 1, which Regulates the Production and Management of Construction and Demolition Waste). Ministry of the Presidency, Madrid, Spain. BOE 038 of 13/2/2008.

Spanish Government - Ministry of the Environment, 2009. Plan Nacional Integrado de Residuos 2007-2015 (National Integrated Waste Plan 2007-2015). Ministry of the Environment, Madrid, Spain. BOE 049 of 26/2/2009.

Symonds, 1999. Construction and Demolition Waste Management Practices, and their Economic Impacts. Report to DGXI, Final Report. European Commission.

Wang, J.Y., Touran, A., Christoforou, C., Fadlalla, H., 2004. A systems analysis tool for construction and demolition wastes management. Waste Management 24, 989-997.

World Commission on Environment and Development (WCED), 1987. Our Common Future. Oxford: Oxford University Press.

Yost, P. and Halstead, J., 1996. A methodology for quantifying the volume of construction waste. Waste Management \& Research 14, 453-461. 